\title{
THE IMPACT OF EDUCATION ON WAGES: ANALYSIS OF AN EDUCATION REFORM IN TURKEY
}

Leyla Mocan

Working Paper 1424

December 2014

This Working Paper is issued under the supervision of the ERF Directorate. Any opinions expressed here are those of the author(s) and not those of the Koç University-TÜSİAD Economic Research Forum. It is circulated for discussion and comment purposes and has not been subject to review by referees.

KOÇ UNIVERSITY-TÜSİAD ECONOMIC RESEARCH FORUM Rumelifeneri Yolu 34450 Sariyer/Istanbul 


\title{
The Impact of Education on Wages: Analysis of an Education Reform in Turkey
}

\author{
Leyla Mocan
}

Federal Reserve Board of Governors

Leyla.Mocan@frb.gov

\begin{abstract}
In 1997 Turkey passed a law making middle school completion compulsory, increasing the mandatory education from 5 to 8 years. At the time of this policy change, only 3 -in- 5 students were completing middle school in Turkey. In this paper, I employ data from the 2011 and 2012 Turkish Household Labor Force Survey to investigate the effect of this law on educational attainment, the impact of the increase in education on wages, and to explore how this varied across individuals. The results indicate that the fraction of children completing middle school increased more than 20 percentage points as a result of this reform. The effects were especially pronounced for girls (particularly those living in rural areas): I estimate that as a result of the reform, an additional half a million girls attained a middle school diploma. There are also considerable spillover effects into high school completion rates. Despite the large policy-induced increase in educational attainment, I find little evidence of a corresponding increase in labor force participation or full-time work. The results suggest large wage gains of about 14 percent per year of schooling, with these benefits concentrated among females. Taken together, the findings demonstrate that the policy change induced a dramatic change in educational attainment among the youth of this predominantly Muslim developing country, but that the economic benefits of the change were limited to women.
\end{abstract}

I thank Mark Duggan for his guidance and helpful comments and Alptekin Avcioğlu, Berk Avcioğlu, Ekrem Cunedioğlu and Bahadir Dursun for their help in obtaining the data. Michael Grossman, Nate Barrett, Colin Cannonier, Aysit Tansel and seminar participants at the $38^{\text {th }}$ Annual Conference of the Association for Education Finance and Policy in New Orleans on March 15, 2013 as well as participants of the Carroll Round Conference at Georgetown University provided valuable comments. I thank Martin Asher, Bethany Schell, Walter Licht, Arlene Fernandez and David Grossman for their support. Summer funding for this research was provided by Wharton SPUR Program. I thank the Trustees' Council of Penn Women and the Wharton Public Policy Initiative for providing travel funding for the AEFP Meeting and the Carroll Round. Finally, I thank Naci Mocan for his support and encouragement.

The views expressed in this paper are solely the responsibility of the author and should not be interpreted as reflecting the views of the Board of Governors of the Federal Reserve System or of any other person associated with the Federal Reserve System. 
The Impact of Education on Wages: Analysis of an Education Reform in Turkey

"Milletleri kurtaranlar, yalniz ve ancak öğretmenlerdir" "Teachers are the one and only people who save nations"

-Mustafa Kemal Atatürk

\section{$\underline{\text { I. Introduction }}$}

In 1997 Turkey passed a law that made middle school completion compulsory. As a result, the middle school completion rate increased from only 60 percent to over 90 percent. I exploit exposure to the sudden onset of this education reform as an instrument for educational attainment to estimate the causal impact of education on workers' wages. I compare workers who just missed the reform's mandate because they were too old in 1997 to those who were in the first cohorts to be impacted by it. These two groups of individuals are for all accounts similar except that those in the "treatment" group happened to be born a few years later and therefore were forced by the legislation to attain more education.

The design allows for an analysis of the general equilibrium effects of this education mandate. This is due to two factors. First, the reform was implemented universally across the country the country. As shown in Figure 1, the reform created a significant increase in educational attainment for the students in grade 5 and younger starting in the fall of 1997. Before the reform, only 3-in-5 workers in Turkey were attaining a middle school education. I show that, after the implementation of the reform, this number increased by about 20 percentage points and, in less than ten years after the reform, over 90 percent of students were completing middle school or a higher degree. Second, in using 2011 and 2012 data, a sufficient amount of time has passed between the implementation of the reform in 1997 and the time of survey for the impact of the reform to diffuse through the economy via various channels such as labor supply and employment propensities, the demand for labor, and industrial composition. 
The existing estimates of the returns to education are obtained mostly using data from developed counties. These studies find that in Western and developed countries each additional year education has an earnings return somewhere between 7 and 10 percent (Angrist and Kruger 1991, Bonjour et al. 2003, Webbink 2006, ) although Oreopoulos (2006) reports larger returns of 10-14 percent using the change in the legal school-leaving age in the United Kingdom. Limited evidence on developing nations suggests that returns to education is larger in these countries (Duflo 2001, Heckman J. and Xuesong Li 2004, Fang et al. 2012). Obtaining reliable estimates of the impact of education on wages and earnings in developing nations are important for policy, and this paper contributes to this effort.

Turkey's legislation is interesting to consider because of the larger global position of the country. In 2011, Turkey's GNI per capita was $\$ 10,410$, putting the country in the World Bank's upper-middle income category. Life expectancy at birth is 74 years and 99 percent of 74 million people living in Turkey have access to an adequate amount of water from an improved source. Furthermore, Turkey has the $18^{\text {th }}$ largest economy in the world with an average annual growth rate of 5 percent over the last decade (World Bank). Yet Turkey is still a developing country. The infant mortality rate is 12 out of 1000 live births, which is higher than Malaysia, Cuba, or Saudi Arabia (World Bank) and the poverty rate is 18 percent (World Bank). The country is ranked only as "partly free" in evaluation of political rights and civil liberties (Freedom House 2014). It should also be noted that only about one quarter of women participate in the labor force.

Turkey is also interesting to analyze because of its position as a predominantly Muslim country straddling relationships with both Europe and the Middle East. Thus, its own policies and their effectiveness may provide relevant information for a wide-range of countries that are similar from a cultural or economic development perspective. 
The findings demonstrate that the reform in Turley did have a significant effect in increasing middle school completion and that it had a larger effect among women. ${ }^{1}$ The reform also increased both the high school and college completion rates, while decreasing the propensity to complete a vocational high school. I find that the return to middle school diploma among men is not statistically different from zero. On the other hand, the return is approximately 14 percent per year for schooling among women with a high school education or less. This finding is similar to results from studies in other developing countries (Duflo 2001, Fang et al. 2012) ${ }^{2}$.

\section{Literature Review}

Estimating the causal effect of education on wages is complicated because it is necessary not only to control for factors that impact wages but also to control for other factors that are closely correlated with both education and wages. Although it may be possible to control for some of these factors, others are not easy to measure. For example, intelligence and motivation may impact both educational attainment and wages; however, a data set containing wage information is unlikely to have information on respondent's IQ level or motivation.

Some studies have used twins to control for genetic makeup and family background and compared wages of twins who have differing levels of education. These studies typically find returns to education between 7 and 9 percent (Ashenfelter and Rouse (1998), Bounjour et all (2003)), but

\footnotetext{
${ }^{1}$ The effectiveness of such a reform remains relevant as Turkey once again changed its compulsory schooling laws in January 2012 to now mandate high school education as well (Finkle, 2012). It should be noted that under the 1997 Law students stayed at the same school for grades 1-8. The 2012 legislation mandates 12 years of schooling such that students can now move into a new school after the first four years. This enables students to start religious education in grade 5 instead of having to defer to grade 9 under the 1997 law. Showing that the policy in 1997 was actually effective is useful as the country moves forward in implementing compulsory schooling laws one more time.

${ }^{2}$ It should be noted that the Fang et al study finds a 20 percent return to one additional year of education in China. This estimate is considerably higher than my findings and other similar findings for developing countries, which tend to estimate single digit returns per one additional year of school.
} 
these exercises still have shortcomings. For example, it is unclear why one twin is able to attain more education than the other. In fact, a recent study by Sandewall, Cesarini and Johannesson (2014) finds that controlling for IQ reduces the returns to schooling obtained from twin-based models in a large sample of monozygotic twins from Sweden.

As an alternative strategy, exogenous 'natural experiments' have been used as instruments for individuals' level of education. Angrist and Krueger (1991) use quarter year of birth as an instrument and consider students' birth dates in proximity to the age in which they start schooling (and thus the age in which they can drop out of school). Using this instrument, Angrist and Krueger find that individuals have on average a 7.5 percent higher wages as a result of one additional year of education. It should be noted that these policies affect people on the margin - not those who would have gone onto college anyway or dropped out of elementary school, but those students who perhaps would not have completed the additional year of schooling but were forced to because of the state law.

Oreopoulos (2006) uses the change in the legal school-leaving age in the United Kingdom that had a major effect on the dropout behavior of 14 to 15 year olds. He compares his estimates of the returns to education to the local average treatment effect obtained from the U.S. and Canada and finds large returns of 10-14 percent per year. Furthermore, he demonstrates that the local average treatment effect found by previous research and the average treatment effect in the population in his study are similar. He concludes that the unbiased estimates of return to schooling are substantial regardless of the size and coverage of the treatment.

Similar studies have found returns to one year of education in developed countries to be between 6 to 10 percent (Brunello, Fort, Weber 2009, Maurin and Xenogiani 2007, Webbink 2006). Studies in developing countries find somewhat larger returns. For example, Duflo (2001) finds that reforms in Indonesia created a return up to 11 percent per year of schooling, and Heckman and Li (2004) report that for a young Chinese person from an urban area, college attendance increases 
lifetime earnings by 43 percent. Fang et al. (2012) find a 20 percent wage increase per year of schooling in China. ${ }^{3}$

There also exists a small body of work on returns to education in Turkey. Krueger (1972) examines the returns to higher education in Turkey by using the 1965 Turkish census. She finds a 2025 percent return for secondary school and university education. Tansel (1994) uses data on urban wage earners who were 15-64 years old in 1987 and finds that the return to an additional year of education ranges from 9 to 22 percent for men, and 3 to 18 percent for women, depending on their level of education. In more recent work, Tansel and Daoud (2011) report that returns to education are 4-10 percent for men and 6-15 percent for women in Turkey. None of these studies, however, accounted for the endogeneity of education. Furthermore, these studies were unable to use the 1997 reform that I exploit in this paper because students were, until recently, too young to plausibly be working full time in the labor force. Specifically, the students who were affected by the reform in 1997 are in their 20's today (2014), so it is now possible to study the effect of the law on their labor outcomes.

\section{Overview of the Turkish Legislation}

In 1997 Turkey passed the Basic Education Law (No. 4306), which increased compulsory education from five years to eight years. Since the start of the Turkish Republic in 1923, compulsory education entailed only five years of primary school. The 1997 legislation was the first change in the compulsory education law since 1923 to create a substantial impact on the level of attained education.

There were many reasons for the passage of the 1997 legislation, the majority of which were political. In 1996 Turkey officially entered the European Customs Union and there was serious

\footnotetext{
${ }^{3}$ In developing countries where the baseline of educational attainment is lower, the returns to even a small increase in education are large and significant.
} 
concern from the Turkish government that European Union membership negotiations would not begin without a universal standard of eight years of mandated education (Dulger 2004). The law also was an attempt by a secular government to restrict religious education by extending the minimum mandated secular education to eight years. In the old system, students could start religious or vocational schooling immediately after their five years of mandated elementary education were complete. With the implementation of the 1997 law, however, students who would elect for religious education would be forced to wait another three years to begin such instruction. The passage of Law No. 4306 closed down all vocational and religious electives such that all students now faced a standardized eight-year curriculum (Dulger 2004). All these political motives may have led to the fact that the law was passed extremely quickly and with little to no public discourse.

Starting in the fall of 1997, all students enrolled in grades 1-5 were mandated to complete 8 years of primary education. Before this time, only about 60 percent, or 3-in-5 students were completing middle school. The law sought to quickly increase this number, primarily by encouraging enrollment. The government was able to immediately and successfully begin increasing enrollment due to several factors. First, there was significant support from outside agencies such as the World Bank, IMF and other NGOs, which helped to quickly put the law into action. Furthermore, the private sector in Turkey made substantial contributions to fund the efforts. Along with raising taxes, this support has allowed the national government to spend $\$ 3$ billion annually to fund the reform (Dulger 2004). The government immediately took action by increasing both the number of schools as well as the number of teachers. Furthermore, the financial incentives for teachers to serve in rural areas were also increased. In any rural areas where schools could not be built quickly, the government established bussing programs to bring students to nearby schools (OCED 2007). In some cases when schools were too far away for students to commute, the government offered enrollment to free boarding schools. Finally, the government abolished the primary school diploma, instead only offering a diploma once eight years of school (compared to five) had been completed. Prior to the 
legislation, students could have received an elementary school diploma after 5 years of school. The new law made it only possible to receive a diploma once elementary and middle school had been completed. It was hoped that the abolishment of a five-year diploma would help incentivize staying in school for the extra three years.

Though at the time the law was heavily criticized for its quick enactment and lack of public discourse, the legislation was ultimately able to quickly begin enrolling record numbers of students into schools. The combination of all previously mentioned efforts dramatically increased the percentage of students who completed middle school. It should be noted that I observe only the highest level of attained education for students and have no metric for the quality of schooling. Especially in the first few years after the reform, it is likely that school quality was diminished, either by larger class sizes or less qualified teachers as the government scrambled to meet the new demand. Additionally, even 10 years after implementation the middle school completion rate did not reach $100 \% .{ }^{4}$ However, these compliance rates are similar to what is achieved in Europe (Brunello 2013). Still, even with this potentially reduced quality of schooling and inability to have $100 \%$ of children in school, I find evidence of some significant returns to education for those students who were on the margin and received an extra three years of schooling as a result of the reform.

\section{Dataset and Methodology}

I use data from the 2011 and 2012 Household Labor Force Survey (HLFS) in Turkey, made available by the Turkish Institute of Statistics ${ }^{5}$. This survey is conducted annually in Turkey and is similar to the United States Current Population Survey. The HLFS collects demographic information,

\footnotetext{
${ }^{4}$ This may be partially attributed to some families asking for request to have their children exempt (especially for rural girls), or to the fact that some families may have opted to willfully ignore the mandate. This is most likely to be the case in rural areas, especially if the local municipality is not aggressive about truancy and upholding the mandate.

${ }^{5}$ For Figures 5-7 in the paper I use the 2002, 2004, and 2006 HLFS datasets, respectively. These datasets are by all means equal to the 2011 and 2012 HFLS, except that ages are reported in groups instead of distinct years. See Section 6 for more details.
} 
including age, sex, marital status, living arrangements, location of residence, highest level of completed schooling and so on. Beyond these demographic questions, the survey primarily asks questions about behaviors and outcomes related to work. This includes employment status, sector of employment, wages, bonuses, and firm size. I consider people ages 20-29 in 2011 and 21-30 in 2012, who would have been ages 6-15 when the reform took place in 1997 . The treatment group contains those age 20-24 in 2011 and 21-25 in 2012, since they would have been ages 6-10 in 1997 and therefore surely affected by the reform. I use those age 26-29 in 2011 and 27-30 in 2012 as my control group, since they would have been age 12-15 in 1997 and therefore would have just missed the reform. For those who were 11 in 1997, half would have been treated and half would have missed the legislation, depending on their month of birth. Because the data do not allow me to accurately determine the month of birth, I assign a value of $1 / 2$ to everyone who was age 25 in 2011 or 26 in 2012, thus giving this group a 50 percent probability of treatment. All estimates are robust when I omit these people all together. The dataset contains 150,335 observations for the most inclusive sample, which considers both sexes and all education levels from ages 20-30 (20-29 in 2011 and 2130 in 2012).

For all analyses the dummy variable "Middle School Completion or Higher" refers to completing middle school or a higher degree of education (high school, university, graduate work etc.). This allows me to capture everyone in the sample who has at least a middle school diploma. The survey only asks for the highest level of completed education, therefore imputing the years of schooling creates an estimate that is rough at best. For example, a student may declare their highest level of completed education as elementary school. Thus, they could be assigned a value of 5 for the measure of completed years of school. However it is possible that the student could have been in school through $7^{\text {th }}$ grade, for example, but did not complete the $8^{\text {th }}$ grade. This would mean that they really had seven years of schooling instead of five. As a result, the measure of years of schooling will understate the true value and make students who completed $5^{\text {th }}$ grade and those who completed $7^{\text {th }}$ 
grade look the same. This makes a binary variable for completion of middle school or higher a more useful measure of educational attainment than the crude measure of years of schooling.

For my analysis of wages, I first constrain the regressions to those whose highest level of education is high school or less. This is because I show that the reform increased both the propensity to complete middle school as well as high school education (see Appendix). The assumption of this approach is that the reform did not directly affect the composition of children pursuing schooling beyond high school. In a companion set of analyses I also run wage regressions using the entire sample without constraining education level.

Respondents in the survey were classified as working, not working but seeking work, or not seeking work at the time of the survey. Those who were working were asked, among other things, their working hours for the current workweek as well as their average hours worked. The sample averages of these two questions were extremely close, which suggests that there was little overreporting in working hours. Thus, I use the number of hours worked in the past week as my general measure of labor supply. This variable is used both as a cutoff for those working full time (defined as working more than 30 hours per week) as well as in the calculation of hourly wages.

The survey asks various questions about wages for those who are currently working, including the amount that the respondent earned in the previous week (reported in New Turkish Lira). A variable for the survey year beginning in 2011 is included in all regressions to control for the effect of inflation that may have lead to wage increases between the 2011 and 2012 surveys. In regressions run on wages, I also control for the effect that working in a small firm versus a large firm may have on wages, as it has been demonstrated in the literature that firm size may be predictive of wage 
levels. ${ }^{6}$ Respondents working at the time of the survey indicated the number of people in their work place. In the sample, the majority of firms fall into the bracket containing 10 to 24 employees. I label a firm as "small" if it has fewer than 10 employees. As shown in Table 1, about 34 percent of the full-time workers with any level of education and about 43 percent of those who have a middle school education or less work in small firms.

\section{$\underline{\text { V. Summary Statistics }}$}

Table 1 presents the definitions and the descriptive statistics of key variables for the whole sample, treatment and control groups for both males and females. Note again that the treatment is associated with exposure to a mandated education of eight years, which is equivalent to middle school diploma. The sample presented in the top panel of Table 1 contains 144,247 observations for those who were age 20-29 in 2011 and 21-30 in 2012 and have non-missing information on education, age, gender and location of residence. This sample is also used to estimate the impact of the reform on education. People who were 24 and younger in 2011 (25 and younger in 2012) would have certainly been forced into obtaining more schooling as a result of the reform. In the regressions these individuals are considered to be "treated" by the law and are assigned a dummy value of 1 . People ages 26 to 29 in 2011 (27-30 in 2012) would have missed the reform and are assigned a value of 0 for the treatment variable. I cap the maximum age at 30 because I do not want the range of ages to become too wide; for example those who are 35 are not necessarily comparable to those who are 20.

The top panel of Table 1 shows that the percentage of individuals who completed middle school or higher is larger in the treatment groups for both males and females. Of males who just

\footnotetext{
${ }^{6}$ There has been significant literature on the effect of firm-size on wages. See the wage outcomes section for more discussion.
} 
missed the reform only 67.8 percent completed middle school or higher; this jumps to 91.1 percent for the treatment group. This difference is even more dramatic for females, given that only 48.5 percent of the control group completed middle school or higher, compared to 78.3 percent of the treatment group.

The bottom panel of Table 1 presents the descriptive statistics for individuals for whom the highest education achieved is high school and who work at least 30 hours per week. Here, the male treatment group has a higher percentage of individuals working in small firms in comparison to men in the control group, while the female treatment group has a probability of working in a small firm that is not statistically different from the control group. Yet again, the raw means presented in Table 1 do not capture effects from other variables. For example, controlling for province ${ }^{7}$ is important because people living in rural areas are more likely to work in small workplaces, yet this effect is not captured by the means alone.

In the unadjusted weighted means reported in Table 1, the treated males and treated females (younger individuals, ages 20-24 in 2011 and 21-25 in 2012) have a lower mean wage than those in the control group. For example, consider full-time female workers with all education levels. Those in the control group with any level of education have an hourly mean wage of 6.1 New Turkish Lira (approximately 3.4 US Dollars), while females in the treatment group have a mean wage of $4.3 \mathrm{New}$ Turkish Lira (approximately 2.3 US Dollars). This is likely because experience contributes greatly to wage levels, and younger individuals (who are in the treatment group), have less experience than older ones who are in the control group.

Finally, the bottom panel of Table 1 presents similar results, only constraining to those who are working and have an education of high school or less. This group will become important and they

\footnotetext{
${ }^{7}$ From here on when I refer to "province" I am citing the 24 NUTS2 classifications of areas in Turkey.
} 
will be of interest in later regressions. Examination of this section of Table 1 shows that the same general patterns as above hold. For example, while the mean probability of completing middle school or higher is 0.853 for males in the control group, it is only 0.494 for the treatment group. The same trend follows for females, with a probability of 0.820 for those who are treated and 0.505 for those in the control group.

\section{The Impact of the Reform on Educational Attainment: Graphical Evidence}

Before using the implementation of the reform as a plausibly exogenous source of variation in educational attainment, it is necessary to demonstrate that the reform did in fact create a significant change in the propensity to complete middle school. While passing legislation is a significant act, generally the more difficult part is the implementation of that legislation. By a herculean effort, the Turkish government was able to actually put the legislation into practice in only a few months after it was passed. This was possible primarily through busing and boarding schools in rural areas which temporarily brought students into schools before there was time to build new schools and hire more teachers. The reform is a plausibly strong instrument because its quick passage and implementation gave people little time to adjust their behavior in response, thus allowing it to be a shock to educational attainment only.

Graphical representation of the percentage of individuals who completed middle school or higher demonstrates the dramatic increase in educational attainment as caused by the legislation. In Figure 1, age in 2011 is measured along the horizontal axis, with percentage per age group having completed middle school or higher along the vertical axis. The averages depicted in Figure 1 are calculated using sampling weights. About 50 percent of 32-33 year old individuals have at least a middle school education in 2011. As expected, the rate is lower for older individuals, and higher for younger ones, due to the significant trend in increasing educational attainment. Thus, older cohorts have less education than younger cohorts as depicted by the downward trend in Figure 1. There is a 
sharp break, however, from this trend for those ages 25 and younger in 2011. As mentioned above, while some of the 25 year-olds would have been treated by the reform, all those ages 24 and younger in 2011 would have certainly been treated by the reform. Figure 1 shows a clear jump in the rate of middle school completion for those who are 25 or younger in 2011 , demonstrating that the passage and implementation of the law did have a significant impact in increasing the level of attained education. Figure 2 presents the same information using the 2012 survey, where the horizontal axis shows age in 2012. Figure 2 is very similar to Figure 1 with one difference - as expected, the jump in average middle school completion rate is now observed among the 26 year olds, as well as the 25 year olds.

The average effect of this legislation was different for males and females. As shown in Figure 3, the fraction of girls completing middle school was also around 1-in-2 prior to the policy change and this sharply increased for subsequent cohorts. In Figure 4, I display these rates for rural females, a group differentially targeted by the reform. As the figure makes clear, educational attainment was much lower initially for females living in rural areas and the jump in attainment was substantially larger for them as well.

Furthermore, the legislation was also differentially targeted at some groups, most notably, females living in rural areas. Through targeted busing and extra funding to these rural areas, the government significantly increased the number of rural girls enrolled in public schools. Figure 4, which presents the rate of middle school completion among rural females for various cohorts in 2011, shows the effectiveness of the reform for this group. The percent of rural females completing at least a middle school is about 30 percent for 26 and 27 year olds, but is its nearly 70 percent for 22 and 23 year olds. This is a large and clear change in a small amount of time. While other subgroups, like urban females, urban males and rural males also showed significant gains, for the sake of brevity I only present the graphs for all females (Figure 3) and for rural females (Figure 4) as they were the targeted group for the legislation and showed the most dramatic changes. 
In summary, Figures 1 through 4 show that the reform created significant variation in educational attainment that can be used to estimate the effect of schooling on wages and other market outcomes. Of course, it should be mentioned that these figures only account for the number of diploma completions and do little to provide information about the relative quality of the schooling these treated cohorts face. To the extent that class sizes increased as a result of the reform or newly hired teachers were not as skilled as incumbent teachers, the policy may have affected the quality of schooling for those who already would have completed middle school. I discuss this issue further below.

Though Figures 1-4 show a clear break in the middle school completion rates between those who were young enough to be treated by the law and the older cohorts, this is not definitive evidence that the legislation is what created this jump. It can be argued that there is something special that has happened to those age 24 and younger in 2011 (25 and younger in 2012) that caused this break in the educational attainment trend. To investigate whether this is the case, I consider Household Labor Force Survey data from the years of 2002, 2004 and 2006 (Figures 5, 6, \& 7). The surveys in these years asked people for their age in brackets $(15-19,20-24,25-29,20-24$ etc.) instead of their age to the specific year. Therefore, for the sake of comparison, I reclassify the 2011 data so that ages are reported in brackets identical to the earlier survey (which is plotted in Figure 8). I once again graph the percentage completing middle school or higher on the vertical-axis and plot the age brackets on the horizontal-axis.

People who were 15 and younger in 2002 would have been the first to be treated by the 1997 reform. In Figure 5, the first age group in the horizontal axis is $15-19$. This means that only $1 / 5$ of the people in this age bracket in 2002 would have been treated by the reform. Figure 5 is consistent with this as it shows perhaps a slight but not hugely noticeable break in the trend of middle school completion. About 45 percent of those who are 25-29 years old in 2002 have a middle school diploma. The rate goes up to about 55 percent for those who are 20 to 24 , and it about 63 percent 
among those who are $15-19$ in 2002 . Thus, Figure 5 mostly demonstrates the general age trend that we would expect in plotting educational attainment.

Figure 6 uses the data from the survey conducted in 2004. Those who were 17 and younger in 2004 would have been treated by the reform. That is, $3 / 5$ of the people in the $15-19$ age bracket in 2004 would have been treated. Therefore, the rate of middle school completion should be higher among the 15-19 year olds in 2004 compared to 15-19 year olds in 2002. In fact, the middle school completion rate in 2004 is 70 percent among the 15-19 year olds, when it was 63 percent for the same age group in 2002 (see Figure 5). ${ }^{8}$

Two years later in 2006, those people who were treated by the reform would have been ages 19 and younger. This means that the entire 15-19 age bracket in 2006 felt the effect of the legislation. This is represented by a large dot in Figure 7. Now the jump in Figure 7 is even more pronounced than the jumps in Figures 5 and 6. Specifically, in 2006, the middle school completion rate is about 58 percent among the 20-24 year olds, which is similar to the rate among the same age group in 2004 and 2002 (see Figures 5 and 6). However, the middle school completion rate jumps up to more than 80 percent among those who are 15-19 in 2006. So, there is more than 20 percentage point difference in middle school completion rate between the treated group (15-19 year olds in 2006) and the non-treated group (20-24 year olds in 2006).

Finally, in the 2011 survey data, all individuals ages 24 and younger would have been treated by the reform. Figure 8 shows that in 2011 data, there is a large jump in the rate of middle school completion for both the 15-19 age bracket and the 20-24 age bracket. In other words, the cohort that was the first to be treated had higher levels of middle school completion and when looking at graphs

\footnotetext{
${ }^{8}$ Note that the dot in Figure 6 for the 15-19 age group is larger than the dot in Figure 5 for the same group, demonstrating that a greater proportion of students in that age bracket were treated by the reform in 2004 than in 2002.
} 
depicted in Figures 5-8, it is clear that this break is moving through time as the cohort aged. This jump is both specific to this cohort and significantly different from the age trend that was already in effect. These graphs, along with the above description of the legislation, strongly suggest that the legislation is the cause of the dramatic increase in middle school completion and a potentially good instrument for educational attainment.

\section{Impact of the Reform on Educational Attainment: Regression Analysis}

Next, I turn to regression analysis to more accurately estimate the effect of the reform on educational attainment while controlling for other factors that may also impact schooling. For example, I control for age, sex, province of residence, firm size as well and year fixed effects. The key parameter of interest is the coefficient on the variable for exposure to the reform, as this demonstrates the impact of the reform on schooling attained. The key assumption in all these analyses is that there were no other factors at the time that would be differentially impacting the educational attainment of the treatment group beyond that captured by the pre-existing trend that is clear from Figure 1.

Regression analyses support and are consistent with the conclusions that can be drawn from examining Figures 1 through 8, which demonstrate the impact of the reform's impact on average educational attainment. Table 2 shows these regression results for different groups of the population.

The results provide estimates of the magnitude of the reform on middle school completion. In the regressions the unit of observation is the individual and the dependent variable is a dummy that equals one if the respondent completed middle school or higher at the time of the survey (in 2011 or 2012), and zero otherwise. The entries are the estimated coefficients from linear probability models and all standard errors are clustered at age-by-province. Clustering by treatment-by-province provides almost the same estimate of standard errors. Here, the key independent variable is a dummy that indicates if the person was "treated by the law," i.e. if they were old enough to be mandated into 
more schooling by the reform. Each regression controls for age, sex and province of residence and urban residence (population of more than 20,000). When I control for these variables, I find that the reform increases the probability of middle school completion by 15 percentage points for all respondents in the sample (column 1 of Table 2).

I next explore whether and to what extent the effect of the reform varies across groups. For example, the results in column 2 of Table 2 demonstrate that the reform increased the likelihood that males graduated from middle school by 13.1 percentage points, but had an even larger impact for females, increasing their probability of completing middle school of 17.0 percentage points (column 3). In percentage terms, this implies an increase by 16 percent for males from their pre-policy average and a 27 percent increase for females. This result is likely because the legislation itself was written to emphasize an increase in educational attainment for the female population, which traditionally has lower educational attainment levels in Turkey than its male counterpart. Given that there are about 3.2 million girls ages 20-24 in 2012 in Turkey, my estimates imply that because of the reform an additional 540,000 women in this age range in 2012 achieved their middle school diploma. Applying the estimates to future cohorts (i.e. those younger than 20) suggests that about 108,000 girls at each age will complete middle school as a result of the reform.

It is also possible to break down the sample by urban and rural subcategories. For males, the effect varies with respect to their status as living in rural or urban areas. The reform made urban males 11.7 percentage points more likely to complete middle school or higher (a 14\% increase), while it made rural males 17.0 percentage points more likely to complete middle school or higher (a $23 \%$ increase). This difference between urban and rural males may largely be attributed to the fact that rural areas had more resources poured into them to implement the legislation. The results are different for females in that the impact was greater for females living in urban areas, with the legislation creating a 17.8 percentage point (26\% increase) increase for those in urban areas compared to a 15.4 percentage point (32\% increase) increase for those living in rural areas. But, 
measured proportionally, the effect of the reform was larger for both males and females in rural areas given the much lower rates of baseline educational attainment there.

It should be noted that the coefficients of the age variable are negative in Table 2, which shows that the older cohorts have a lower propensity to have at least a middle school diploma. This is a representation of the negative trend of schooling as a function of age, shown in Figures 1 to 8.

I also run regressions for the sample of individuals where the highest level of attained education is high school. This means that I am comparing students who completed middle school or high school (but not vocational school, college or a higher degree) to students who completed elementary school or less. The regression results presented in Table 3 demonstrate that the reform increased the probability of obtaining a middle school diploma by 21.7 percentage points in this sample (37 percent increase). For males there is a 22.4 percentage point increase ( 32 percent increase); similarly there is a 21.2 percentage point increase for females, which translates into a 42 percent increase. The greatest increase comes for rural males, who - as a result of the reform - have a 25.6 percentage point increase in the probability of attaining a middle school diploma, which is a 41 percent increase from the sample average of 63.0 percent.

It should be noted that the wage regressions will be estimated by instrumental variables where the reform is the instrument for educational attainment. However, the results presented in Tables 2 and 3 are not the first stage regressions, since they do not correspond to the same sample as in the main wage regressions (only full time workers). The coefficients of interest from the first stage regressions are presented with the IV results in Section VIII below.

I also examine if there is a spillover effect of the law. I run regressions of the probability of completing high school, probability of completing vocational school or the probability of completing college. I find that the reform has increased the probability of completing high school, while it has decreased the propensity to obtain vocational school diploma. In other words, the reforms seems to have moved the students away from vocational schools towards traditional high schools. I also find 
that exposure to the reform leads to a higher probability of college completion. One might worry that this leads people to attain higher education and stay out of the labor force, thus contaminating the results. However, this is unlikely to be true, as the majority of my sample is over age 23 and consequently likely to have completed schooling. More discussion of these results is presented in Appendix Table $1 .^{9}$

\section{Wage Regressions}

Theoretically it is expected that an increase in schooling would result in an increase in wages. First, however, I seek to examine if the shock in additional schooling caused people to join the labor force, to choose full time work over part time, or to have impacted their propensity to work in a small firm. As shown in the Appendix Tables 2, 3 and 4, however, additional schooling did not have an effect on any of these outcomes.

The base equation I estimate is as follows:

$$
\log W_{i}={ }_{0}+{ }_{1} E d u c_{i}+{ }_{i} X_{i}+{ }_{j=1}^{25}{ }_{j} \operatorname{Pr} o v_{i j}+{ }_{i}
$$

where $\log W_{i}$ is the natural logarithm of nominal hourly wages and $E d u c$ is a binary variable for having completed middle school. Potential differences in price levels between provinces are captured by a set of 25 dummies representing the province of residence and by a year fixed effect variable to account for the change in the level of wages due to the survey year (2011 vs. 2012). The vector $\mathrm{X}$ includes age, a binary variable for living in an urban versus rural area, a binary variable that indicates if the worker is working in a small firm (defined as "small" if there are fewer than 10

\footnotetext{
${ }^{9}$ Similarly, Yuret (2010) finds that although the law was targeted at making middle school compulsory, it had a side effect of increasing high school attainment by 3.2 percent.
} 
employees). ${ }^{10}$ Age is an important control to include because people who are older generally have more experience and therefore tend to earn higher wages. Industry of employment is not controlled for because the worker's choice of industry may be determined by education. There is no information in the data about work experience. Although this variable can be approximated as (Age minus years of schooling minus 6), it cannot be included to the regressions because it depends on years of schooling and age and is thus a linear combination of other vectors in the regression. Equation (1) does not include marital status because this is an outcome variable which itself may depend on education. Some individuals may decide to delay their marriage decision as a result of their increased level of education due to the reform, and inclusion of marital status in the wage equation would bias the estimated effect of education on wages (Angrist and Pischke 2009, pp. 64$66)$.

I examine if having a middle school education (by instrumenting middle school completion with the 1997 legislation) creates a significant increase in wages. I consider those workers who are working full time (30 hours or more a week) and who were not enrolled in school at the time of the survey. It should be noted that exposure to the reform does not change the propensity to work fulltime or the propensity to be in the labor force and thus concerns about changes in the composition of workers potentially biasing the estimates are much less of an issue. Specifically, regressions of fulltime work as well as labor force participation on being treated by the reform do not produce significant coefficients. These results are presented in Appendix Table 2 and Appendix Table 3. ${ }^{11}$

${ }^{10}$ It has been shown that both working in an urban area and working at a larger firm leads to increases in wages, thus it is important to control for these variables. Furthermore, I show that the reform had no impact on propensity to live in an urban area or to work at a large firm, thus including these variables in the regression does not cause bias.

${ }^{11}$ In the regressions where full-time work or labor force participation is the dependent variable, these variables are regressed on the treatment dummy, rather than education. This is because full-time work and labor force participation decision depend on wages and wages depend on education. So, the impact 
Note that the data set does not contain information on the month of birth. Even if it did, this would not have been useful for a different type of analysis, such as Regression Discontinuity Design (RDD). This is because the letter of the law regarding the Turkish primary education does not allow the determination of whether a student is supposed to start the first grade based on his/her month of birth. Unlike some other countries, in Turkey the school starting age is not determined by the student's age in September. Rather, students who are 72 months old by the end of the calendar year can start school in September. This means that children who were born in September, October, November or December 1986 were exempt from the mandate of the law. In addition, as explained by Cesur and Mocan (2013), the Ministry of Education does not enforce the 72-month-cutoff; which implies that students who were born in January 1987 may have started school in 1992, so they may have missed the reform. In summary, a formal RDD design is not feasible in this setting.

In order to account for correlation in wages of people of the same age who live in the same area, standard errors are clustered by age-by-province. This created 130 clusters ( 5 age groups times 26 provinces $).{ }^{12}$ I also report standard errors that are clustered at the treatment by province level ( 2 categories, treated or not, for 26 provinces provides a total of 52 clusters) as well as the robust standard errors. For the instrumental variable regressions there is almost no difference between these three methods of calculating the standard errors.

In first set of regressions I cap the highest level of education at the high school level. Given the reform increased the propensity to complete both middle and high school, I first consider students who earned at most a high school education. I also estimate, however, the wage regressions using (i)

of education cannot be identified independently. As a result, I estimate reduced-form regressions of fulltime work and labor force participation.

12 The HLFS partitions the country into 26 provinces. Age is categorized into five groups $(20 \& 21$, $22 \& 23,24 \& 25,26 \& 27,28 \& 29 \& 30)$ and then a cluster is created for each province and group, creating $26 \times 5=130$ clusters 
the sample of workers who attained a middle school education or less, (ii) the sample of workers who have graduated from high school, vocational school or a lower level of education, (iii) and the sample of workers with all levels of education, including those with a college degree or higher. Finally, the top and bottom one percent of the wage distribution are omitted from the regressions, as these constitute outliers, possibly due to reporting/coding errors in salaries or work hours. For example, for women the first percentile of the wage distribution is 0.625 Turkish Lira (about 49 cents) whereas in 2011 the legal minimum wage was 629 Turkish Lira per month, or 3.9 TL per hour (about \$2.1) for a 40-hour work per week.

Table 4 presents the results of the wage regressions from the IV specifications, as well as their OLS counterparts. For the entire sample (which includes both males and females) OLS produces a statistically significant coefficient for middle school completion variable, indicating about 7 percent return to a middle school diploma. The IV estimate is larger and indicates a return of about 10 percent (for three years of additional education - assuming that the average student did complete the mandated three years of middle school education).

As discussed by Oreopoulos (2006), IV estimates could be larger than OLS estimates if the local average treatment effect of the IV only approximates the return for a peculiar, nonrepresentative group. However, he demonstrates that in a large scale education intervention in the U.K., the IV results are similar to those obtained from the local average treatment effects estimated in other studies that were based on limited exposure to treatment. In this paper, the exposure to treatment is nearly universal as the Turkish law mandated middle school completion. Therefore, the IV estimates are likely to be credible, regardless of their magnitude in comparison to OLS estimates.

The results show no statistically significant return to the middle school diploma for males. For females in the sample, however, while OLS estimates produce a significant 18 percent return to 
the middle school diploma the IV estimates show a statistically significant return of 43 percent (about 14 percent per year of schooling). ${ }^{13}$ The sample sizes for females are small at only 4,520

observations because females in Turkey have a very low labor force participation rate. One possible reason that the effects may be larger for females is that having more females in the classroom may increase the returns to schooling for other females who were already attending through middle school by giving them more peers.

The bottom panel of Table 4 presents the mean wages (not in logs) in each sample. It also displays the coefficient of the treatment in the first-stage regression and the F-value of the instrument in the first stage. For all three IV regressions the F-values are well over 10, which suggests that the instrument is strong. The main takeaway from these results is that for males with high school education or less who received additional education as a result of the reform there was little impact, whereas for females there is about a 41 percent return to the diploma, or about a 14 percent return per year of schooling.

The literature has shown consistently that large firms tend to pay higher wages ${ }^{14}$. Some reasons for this may be that large firms are trying to pay higher wages to avoid unionization, or are offering inferior working conditions (Brown and Medoff, 1989). To take this into account, I control for firm size in all my regressions. Consistent with the findings of previous research, I find that Turkish workers in larger firms earn higher wages than those in small firms. Specifically, workers in small firms (those with fewer than 10 workers) earn wages that are 12-20 percent lower than their counterparts in large firms. This impact is largest for women at nearly 20 percent. In the appendix,

13 In this case, the coefficients from the regression are 0.169 and 0.358 , but because the outcome variable is log wage I calculate the effect as $100 x[\exp (0.169)-1] \%$ and $100 x[\exp (0.358)-1] \%$, respectively. For all coefficients over 0.1 , the effect is calculated by the above formula.

${ }^{14}$ For example, it has been shown to be true in Zimbabwe, as well as Ghana and Kenya that large firms pay higher wages than their smaller counterparts (Velenchick, 1997, Soderbom et al, 2004). There is also evidence from the U.S. that workers in large firms get an unexplained wage premium (Troske, 1999). 
I show that having a middle school diploma, induced by the reform, does not change the propensity to work in a small firm.

Column (1) Table 4 also shows that males earn about 14 percent more than females, holding constant age, education, urban residence and firm size. This result is similar to the male-female wage gap reported in other countries.

Table 5 demonstrates the wage regressions for males with different levels of education. Column (2) of Table 5 is the same as column (3) of Table 4, where, for males who have an education of high school less, additional educational attainment has an insignificant effect on wages. As shown in Table 5, this is true for all levels of education for males, including middle school or less, high school and vocational school or less, and all levels of education.

Table 6 shows the same specifications for females. Column (2), which is the same as column (5) of Table 4, shows that the coefficient of middle school completion is 0.358 , indicating that wages of females with a high school education or less are 43 percent higher as a result of the middle school diploma. However, adding the additional 1,200 or so students who completed vocational school (column 3) decreases the coefficient to 0.255 - a smaller return of 29 percent. This is not surprising because vocational high school graduates typically earn wages that are lower than standard high school graduates. Unlike males, analyzing the entire sample of females (column 4 of Table 6) produces a significant coefficient of 0.645 on the education variable. This estimate is very large, though it must be remembered that this group includes anyone from college graduates to those with only an elementary school education, so there is substantial variation in their wages.

A number of potential explanations can be provided for the fact that additional three years of education has an impact on female wages, but no impact on male wages. For example, as shown by the graphs and supported by the results in Table 2, female school enrollment has been impacted more strongly by the reform in comparison to male enrollment, partly because female enrollment rates were much lower prior to the reform. This means that the reform increased female-to-male student 
ratio, which implies that female students in post-reform cohorts had more female peers in comparison to females in pre-reform cohorts. Research has shown that female students' learning and school performance improves as they are exposed to a more female peers (Hoxby 2000). Whitmore (2005) also found that girls do better in a classroom that has a high fraction of girls. Lavy and Schlosser (2011) confirm this finding and report that classroom with larger fraction of female peers improve scholastic achievement of students with a larger impact on girls. ${ }^{15}$ Therefore, having substantially more female peers in the classroom would have significantly impacted cognitive gains of female students, which could explain the impact on wages.

Related to the positive peer-effects explanation, indirect evidence on relatively stronger cognitive gains of female students can be found in the analysis of high school and college attendance. Appendix Table 1 shows that exposure to the reform had a larger impact on females' propensity to attend high school or college. College attendance is particularly noteworthy because it is achieved only after being successful at a centralized nation-wide university entrance exam. This provides suggestive evidence that the additional years of schools due to the education reform has provided more significant cognitive gains for female students. If this is the case, it is expected for employers to substitute on the margin females for males. It has been shown that similar labor substitutions can take place within industries, occupation and education groups for different reasons (Juhn et al. 2014, Autor et al. 2003)

\section{$\underline{\text { IX. Extensions }}$}

To analyze whether the impact of education on wages differs by province, I re-estimated the models using dividing the sample into two by province of residence: Eastern Turkey or

\footnotetext{
15 They report that this effect is working through less disruption, lessened teacher fatigue and better interstudent and student-teacher relations due to having more girls in the classroom.
} 
Western Turkey. ${ }^{16}$ These provinces differ in a number of dimensions, ranging from economic development to cultural conservatism, such that Western Turkey enjoys higher per capita income and higher levels of schooling. While there are many big cities in the West such as Istanbul and Izmir, the East also contains many large cities such as Adana, Gaziantep, Konya, and the capital city Ankara.

When I estimate the wage equation for females with education levels of high school or less using those who live in Eastern Turkey, I find a coefficient of $0.59(\mathrm{p}=0.05)$ for middle school completion with a first-stage F-value of $10.3(n=2,061)$. For the Western sample, the impact of having at least a middle school diploma on log female wages is $0.27(\mathrm{p}=0.01)$, with an F-value in the first stage of $29.1(\mathrm{n}=2,442)$. In other words, the impact of education on wages is about twice as big in Eastern Turkey as in Western Turkey.

Average female wages are higher in the Western part of the country in comparison to the East. Specifically, averages wages in the West are 3.58 Turkish Lira per hour (about 1.72 USD) compared to 3.02 TL per hour in the East (about 1.45 USD). Because the return to wages of additional years of schooling is larger in the East than the West, the education reform effectively had an equalizing effect on the wage gap between Eastern and Western turkey for women. In other words, while women in the East had lower wages, they gained more from the education reform which allowed their wages to converge closer to women living in Western Turkey.

As shown earlier, the impact of education on wages was not significant for men. This finding persists even when the models are estimated by province. For men who live in the East, the

\footnotetext{
${ }^{16}$ The Eastern Turkey group consists of Central Anatolia, The Black Sea Region, Northeast Anatolia, North Central Anatolia and Southeastern Anatolia. The Western Turkey group consists of Istanbul, West Marmara, East Marmara and The Aegean Coast. Specifically, the cities in Western Turkey are Istanbul, Edirne, Tekirdag, Kirklareli, Balikesir, Cannakkale, Izmir, Denizli, Aydin, Mugla, Manisa, Afyon, Kutahya, Usak, Bursa, Eskisehir, Bilecik, Kocaeli, Sakarya, Duzce, Bolu and Yalova.
} 
coefficient of treatment is 0.09 , and not statistically different from zero ( $p=0.23, \mathrm{~N}=78.2$, F-first stage=78.2). For men who live in Western Turkey the coefficient was 0.04 , again not different from zero $(\mathrm{p}=0.50, \mathrm{~N}=7,974, \mathrm{~F}$-first stage $=51.3)$. Thus, we see consistency in the results for men, such that completing middle school diploma having no effect on their wages.

\section{$\underline{X . \text { Conclusion and Discussion }}$}

Although economists have used different methods to estimate the causal effect of education, the overwhelming majority of the studies have used data from developed countries. In this paper I exploit an education reform in Turkey which mandated middle school education for all students, and increased the compulsory education from 5 to 8 years in 1997. I use data from the 2011 and 2012 Household Labor Force Surveys (equivalent to the CPS in the U.S.) and consider treatment by this law based on year of birth as an instrument for educational attainment. I find that (consistent with descriptive evidence presented in Figures 1-8) the law was successful in increasing the propensity to complete middle school or higher. Furthermore, the law increased the propensity to obtain a high school or college degree - with larger effects on women, but it decreased the propensity to obtain a diploma from a vocational high school.

The paper demonstrates that for females there are significant returns to education as a result of a middle school diploma. Instrumental variables regressions show that for men there is no statistically significant wage increase as a result of the additional education. For women, however, the return is 43 percent for the middle school diploma, which is an almost 14 percent return per year 
of school. ${ }^{17}$ Increased education had no impact on labor force participation, full-time work, or the propensity to work in a small firm.

The large returns to education for women are not surprising because of two points. First, female wages on average are low. For example, average female wages of those with at most a middle school education is 3.04 Turkish Lira, which is lower than the legal minimum wage. Furthermore, female wages are about 14 percent lower than male wages with comparable age and education, residential location (urban vs. rural), and controlling for province-fixed effects (although male job experience is likely to be greater). Second, the labor force participation of women is low (about 25 percent) and the results show that the reform did not influence the labor force participation behavior. This means that increased education did not influence female labor supply greatly. Thus, it is unlikely a change in female labor supply that is driving in increase in female wages. Rather, perhaps the increase in female wages as a result in education is manifesting itself through increased demand for female labor. As shown by previous research, substitution between types of labor (male vs. female in this case) can take place even within industries, occupations and education groups (Autor et al. 2003). The reason for enhanced demand for female could be because additional education helped females more than males in terms scholastic achievement and cognitive gains because girls had substantially more female peers in classrooms after the reform, and recent research shows that having more female peers generates substantial academic benefits for female students (Hoxby 2000, Whitmore 2005, Lavy and Schlosser 2011).

In summary, these findings show that mandating middle school completion in Turkey did have a significant impact in terms of increasing attained education, and that increased schooling has translated into higher wages, especially for females. These results have potential implications

17 The returns to education are generally higher in developing countries (Psacharopoulos 1994). For example, Fang et al (2012) estimated a 20 per cent return per year of education in China. 
regarding education mandates in other developing nations, especially for those in the Middle East. Crucial to this, however, is a commitment to bring girls into schools along with boys, as it is clear that there is potential for large gains as a result of these kinds of reforms. 
Figure 1

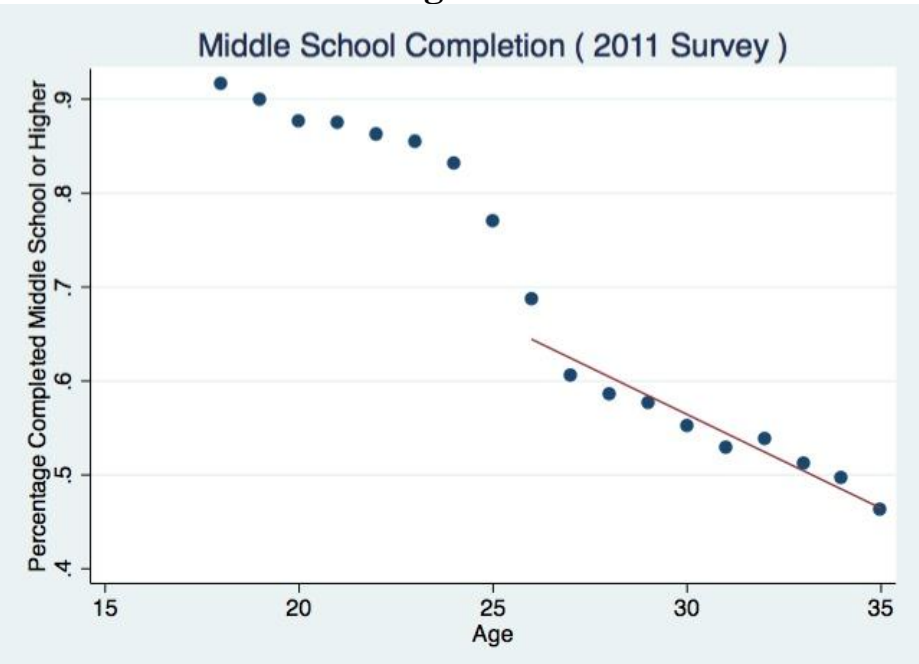

Figure 2

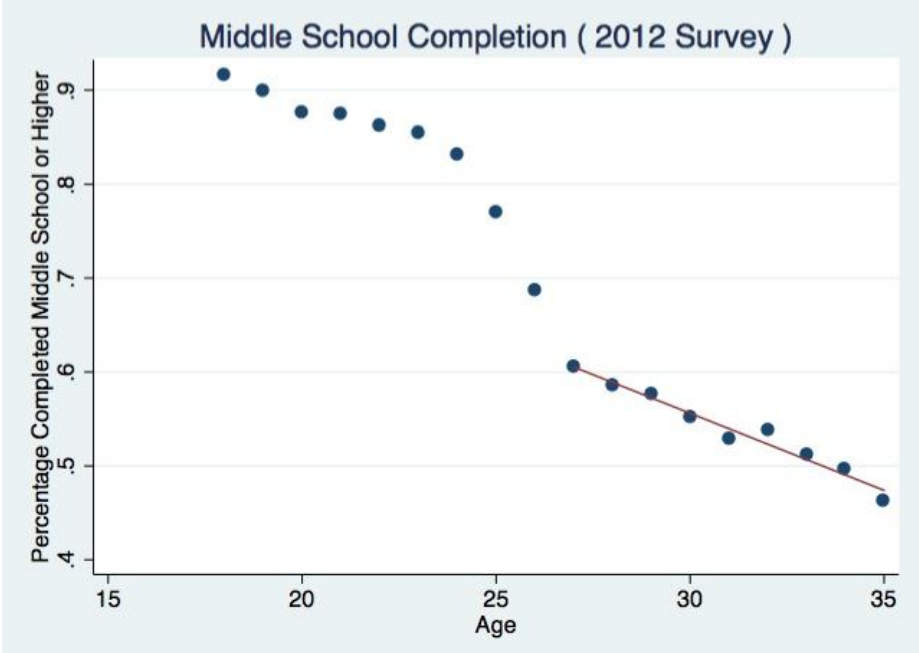

Figure 3

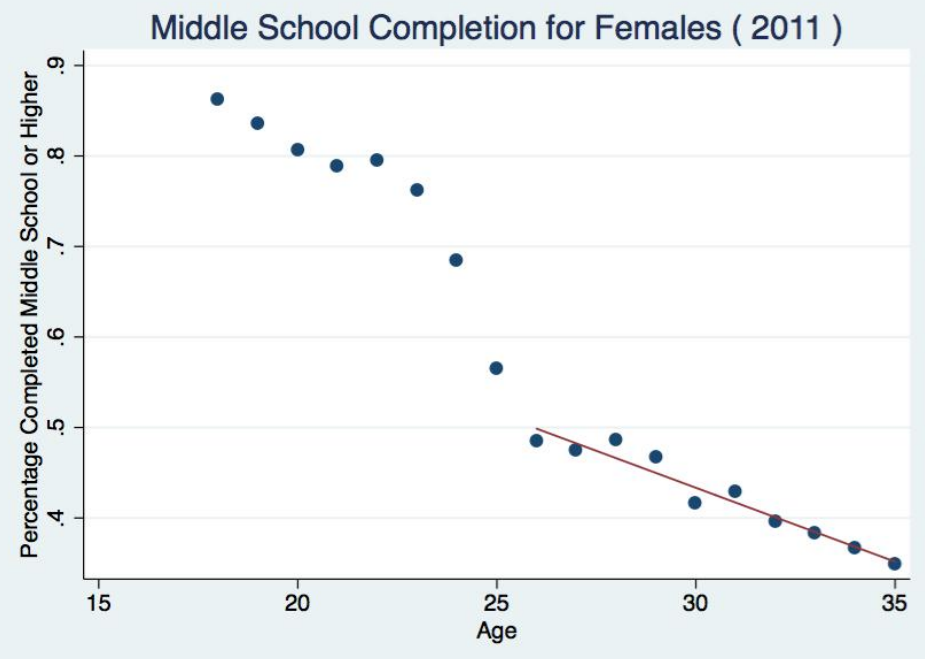


Figure 4

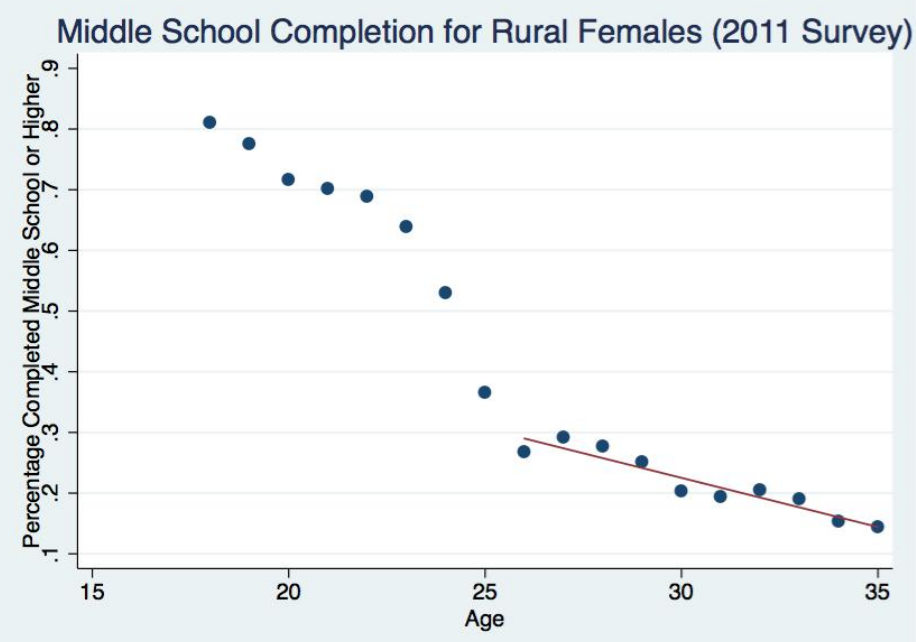

Figure 5*

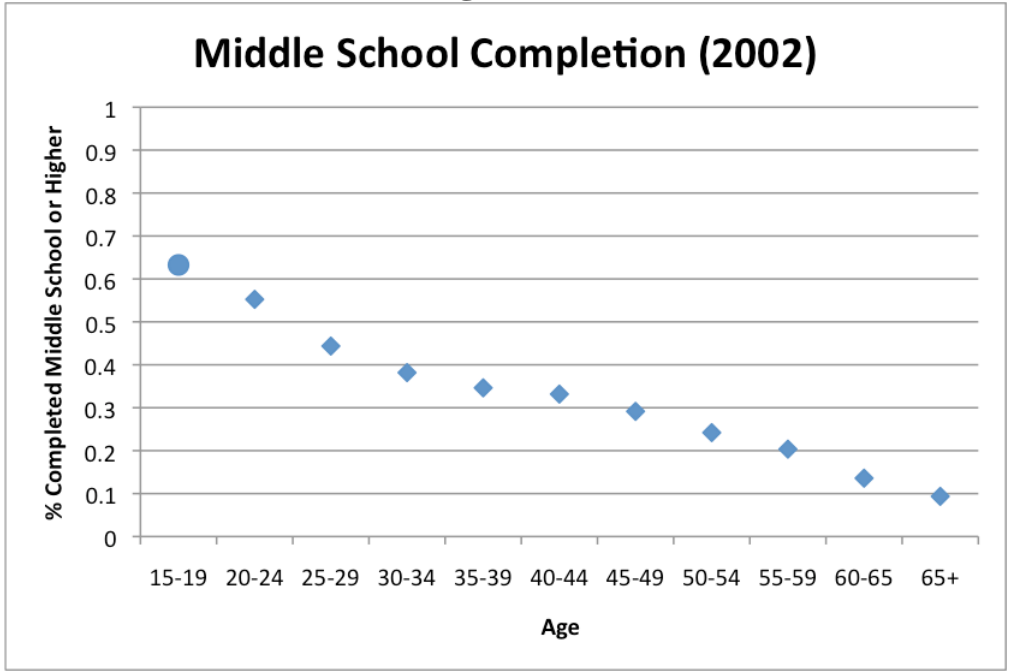

Figure 6*

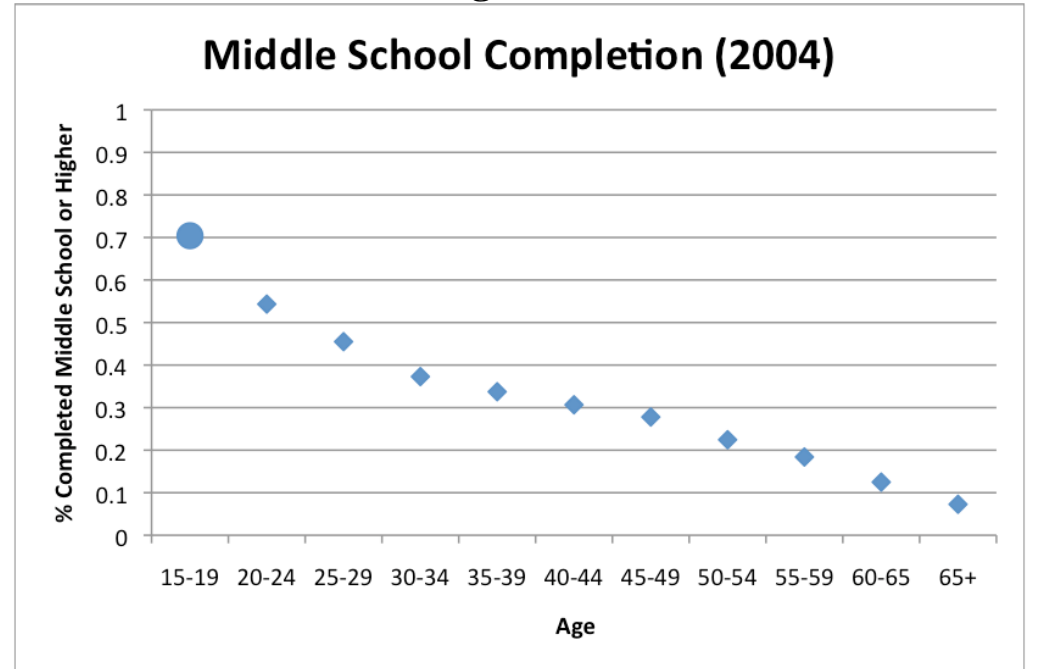

*The size of the dots indicate the relative percentage of students in each age bucket that were affected by the reform. In 2002, 20\% of 15-19 year old students were treated whereas in $200460 \%$ of 15-19 year old students were treated. 
Figure 7*

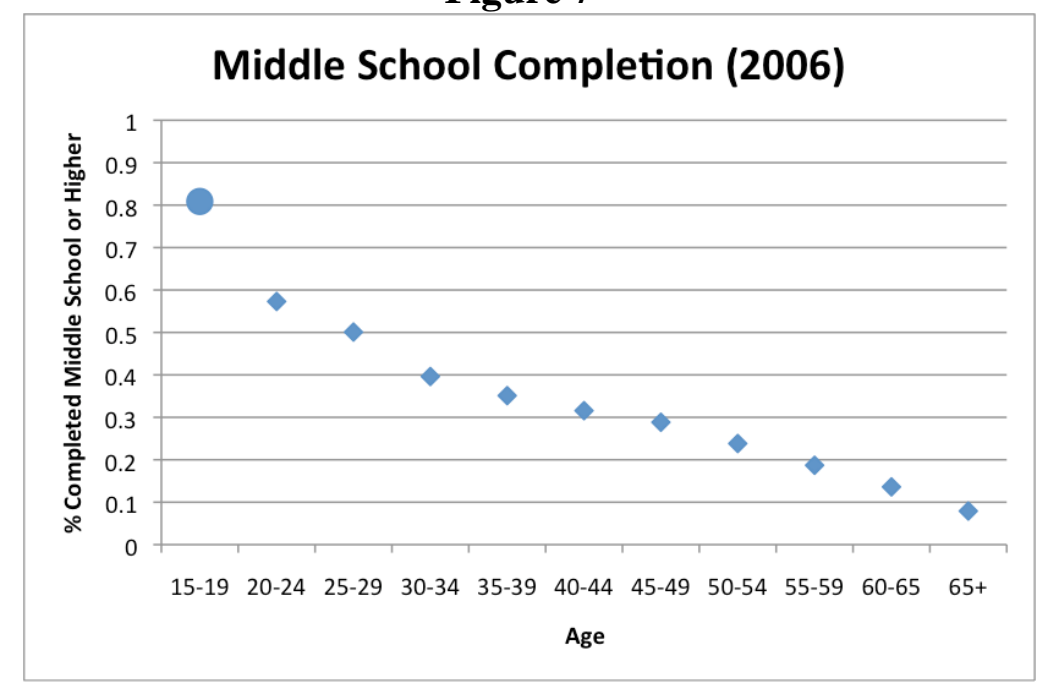

Figure 8*

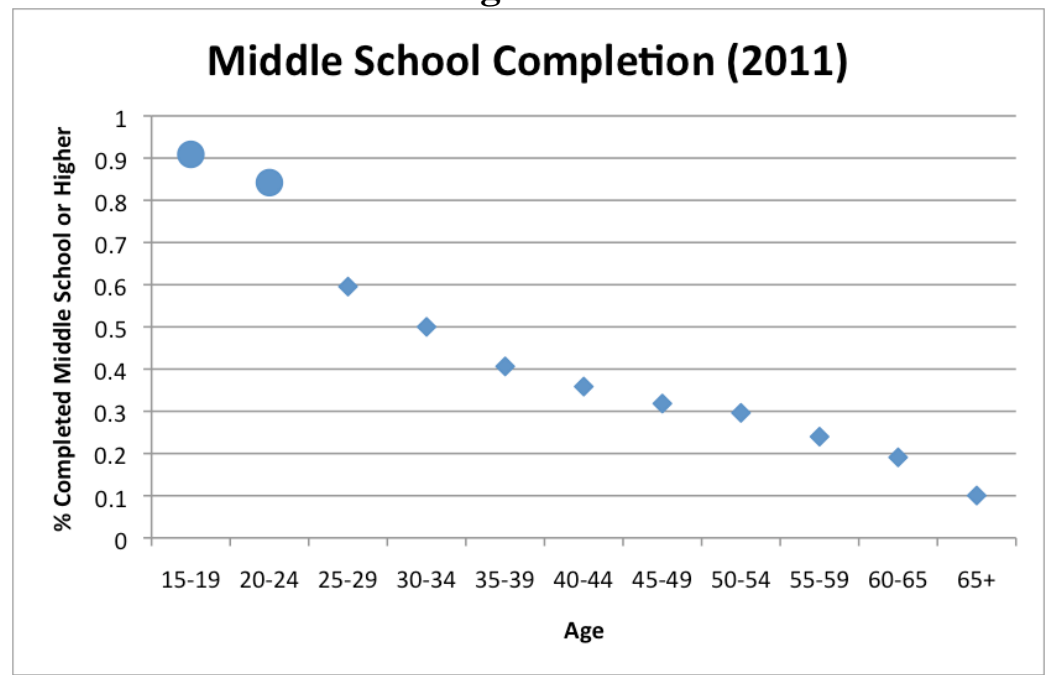

*The size of the dots indicate the relative percentage of students in each age bucket that were affected by the reform. In $2006,100 \%$ of $15-19$ year old students were treated whereas in 2011 100\% of 15-19 year old students and $100 \%$ of 20-24 year old students were treated. 


\begin{tabular}{|c|c|c|c|c|c|}
\hline \multicolumn{6}{|c|}{$\begin{array}{c}\text { Table } 1 \\
\text { Summary Statistics }\end{array}$} \\
\hline Variable & $\begin{array}{c}\text { Entire } \\
\text { Sample } \\
(1)\end{array}$ & $\begin{array}{c}\text { Treated } \\
\text { Females } \\
(2)\end{array}$ & $\begin{array}{c}\text { Treated } \\
\text { Males } \\
(\mathbf{3}) \\
\end{array}$ & $\begin{array}{c}\text { Control } \\
\text { Females } \\
(4)\end{array}$ & $\begin{array}{c}\text { Control } \\
\text { Males } \\
(5) \\
\end{array}$ \\
\hline Middle School & 0.717 & $0.783^{*}$ & $0.911^{*}$ & $0.485^{*}$ & $0.678 *$ \\
\hline Completion & $(0.450)$ & $(0.412)$ & $(0.284)$ & $(0.500)$ & $(0.467)$ \\
\hline $\mathrm{N} t$ & 144,247 & 36,366 & 33,224 & 30,914 & 28,902 \\
\hline & \multicolumn{5}{|c|}{$\begin{array}{l}\text { Full Time Workers with } \\
\text { All Levels of Education }\end{array}$} \\
\hline $\begin{array}{l}\text { Middle School } \\
\text { Completion }\end{array}$ & $\begin{array}{c}0.811 \\
(0.392)\end{array}$ & $\begin{array}{l}0.919 * \\
(0.273)\end{array}$ & $\begin{array}{l}0.904 * \\
(0.295)\end{array}$ & $\begin{array}{l}0.828 * \\
(0.377)\end{array}$ & $\begin{array}{l}0.701 * \\
(0.458)\end{array}$ \\
\hline Small Firm & $\begin{array}{c}0.340 \\
(0.474)\end{array}$ & $\begin{array}{l}0.303 * \\
(0.460)\end{array}$ & $\begin{array}{l}0.415 * \\
(0.492)\end{array}$ & $\begin{array}{l}0.236^{*} \\
(0.425)\end{array}$ & $\begin{array}{l}0.331 * \\
(0.471)\end{array}$ \\
\hline Wage & $\begin{array}{c}4.793 \\
(2.889)\end{array}$ & $\begin{array}{l}4.300 * \\
(2.521)\end{array}$ & $\begin{array}{l}3.988 * \\
(2.159)\end{array}$ & $\begin{array}{l}6.101 * \\
(3.653)\end{array}$ & $\begin{array}{l}5.092 * \\
(2.984)\end{array}$ \\
\hline Urban & $\begin{array}{c}0.832 \\
(0.374)\end{array}$ & $\begin{array}{l}0.861 * \\
(0.346)\end{array}$ & $\begin{array}{l}0.787 * \\
(0.409)\end{array}$ & $\begin{array}{l}0.900 * \\
(0.300)\end{array}$ & $\begin{array}{l}0.834 * \\
(0.372)\end{array}$ \\
\hline $\mathrm{N} \ddagger$ & 42,591 & 4,901 & 11,793 & 5,154 & 15,962 \\
\hline & \multicolumn{5}{|c|}{ Full Time Workers with Education High School or Lower } \\
\hline $\begin{array}{l}\text { Middle School } \\
\text { Completion }\end{array}$ & $\begin{array}{c}0.661 \\
(0.473)\end{array}$ & $\begin{array}{l}0.820 * \\
(0.384)\end{array}$ & $\begin{array}{l}0.853 * \\
(0.354)\end{array}$ & $\begin{array}{l}0.505^{*} \\
(0.500)\end{array}$ & $\begin{array}{l}0.494 * \\
(0.500)\end{array}$ \\
\hline Small Firm & $\begin{array}{c}0.430 \\
(0.495)\end{array}$ & $\begin{array}{c}0.371 \\
(0.483)\end{array}$ & $\begin{array}{l}0.481 * \\
(0.500)\end{array}$ & $\begin{array}{c}0.365 \\
(0.482)\end{array}$ & $\begin{array}{l}0.413 * \\
(0.492)\end{array}$ \\
\hline Wage & $\begin{array}{c}3.626 \\
(1.337)\end{array}$ & $\begin{array}{l}3.190^{*} \\
(1.156)\end{array}$ & $\begin{array}{l}3.452 * \\
(1.240)\end{array}$ & $\begin{array}{l}3.456^{*} \\
(1.298)\end{array}$ & $\begin{array}{l}3.898 * \\
(1.412)\end{array}$ \\
\hline Urban & $\begin{array}{c}0.799 \\
(0.400)\end{array}$ & $\begin{array}{l}0.820 * \\
(0.384)\end{array}$ & $\begin{array}{l}0.770 * \\
(0.421)\end{array}$ & $\begin{array}{l}0.846^{*} \\
(0.361)\end{array}$ & $\begin{array}{l}0.811 * \\
(0.391)\end{array}$ \\
\hline $\mathrm{N}$ & 23,854 & 2,248 & 7,786 & 1,820 & 9,405 \\
\hline
\end{tabular}

$\$$ : The number of observations of columns (2)-(5) do not add up to the number of observations reported in column (1) of the entire sample because the means of the treatment and control groups reported in columns (2)-(5) do not contain, the 25/26-year olds (for 2011 and 2012 respectively. Statistically significant differences at the 5\% level of better between the means of treatment and control groups (by sex) are indicated by *.

The entire sample consists of those ages 20-30 in 2011-2012. Treated males and treated females were age 20-24 in 2011 and 2125 in 2012. Control males and control females were 26-29 in 2011 and 27-30 in 2012 


\section{Table 2}

The Effectiveness of the Reform in Increasing the Propensity for Middle School Completion

(Using people 20-30 Years of Age, with Any Level of Education)

Dependent Variable: Middle School Completion or Higher

\begin{tabular}{|c|c|c|c|c|c|c|c|}
\hline & $\begin{array}{c}\text { Entire } \\
\text { Sample } \\
(1)\end{array}$ & $\begin{array}{c}\text { Males } \\
\text { (2) } \\
\end{array}$ & $\begin{array}{c}\text { Females } \\
(3) \\
\end{array}$ & $\begin{array}{c}\text { Urban } \\
\text { Males } \\
(4)\end{array}$ & $\begin{array}{c}\text { Rural } \\
\text { Males } \\
(5) \\
\end{array}$ & $\begin{array}{c}\text { Urban } \\
\text { Females } \\
(6)\end{array}$ & $\begin{array}{c}\text { Rural } \\
\text { Females } \\
(7)\end{array}$ \\
\hline $\begin{array}{c}\text { Coefficient } \\
\text { of } \\
\text { Treatment }\end{array}$ & $\begin{array}{r}0.149 * * * \\
(0.013)\end{array}$ & $\begin{array}{c}0.131 * * * \\
(0.012)\end{array}$ & $\begin{array}{c}0.170 * * * \\
(0.019)\end{array}$ & $\begin{array}{c}0.117 * * * \\
(0.012)\end{array}$ & $\begin{array}{c}0.170 * * * \\
(0.023)\end{array}$ & $\begin{array}{c}0.178 * * * \\
(0.019)\end{array}$ & $\begin{array}{l}0.154 * * * \\
(0.039)\end{array}$ \\
\hline Age & $\begin{array}{c}-0.023 * * * \\
(0.002)\end{array}$ & $\begin{array}{c}-0.020 * * * \\
(0.002)\end{array}$ & $\begin{array}{c}-0.025 * * * \\
(0.004)\end{array}$ & $\begin{array}{c}-0.017 * * * \\
(0.002)\end{array}$ & $\begin{array}{c}-0.029 * * * \\
(0.004)\end{array}$ & $\begin{array}{c}-0.018 * * * \\
(0.003)\end{array}$ & $\begin{array}{c}-0.046 * * * \\
(0.006)\end{array}$ \\
\hline Male & $\begin{array}{c}0.167 * * * \\
(0.009)\end{array}$ & $\cdot$ & · & - & · & $\cdot$ & · \\
\hline Urban & $\begin{array}{c}0.144 * * * \\
(0.011)\end{array}$ & $\begin{array}{c}0.102 * * * \\
(0.011)\end{array}$ & $\begin{array}{c}0.184 * * * \\
(0.013)\end{array}$ & . & - & $\cdot$ & $\cdot$ \\
\hline $\begin{array}{c}\text { Year Fixed } \\
\text { Effect }\end{array}$ & $\begin{array}{c}-0.026 * * * \\
(0.003)\end{array}$ & $\begin{array}{c}-0.023 * * \\
(0.004)\end{array}$ & $\begin{array}{c}-0.028 * * * \\
(0.006)\end{array}$ & $\begin{array}{c}-0.024 * * * \\
(0.005)\end{array}$ & $\begin{array}{l}-0.018 \\
(0.009)\end{array}$ & $\begin{array}{c}-0.022 * * * \\
(0.005)\end{array}$ & $\begin{array}{c}-0.046^{* * * *} \\
(0.010)\end{array}$ \\
\hline $\begin{array}{l}\text { Province } \\
\text { Dummies }\end{array}$ & Y & Y & Y & Y & Y & Y & Y \\
\hline $\begin{array}{c}\text { Mean } \\
\text { Middle } \\
\text { School } \\
\text { Completion } \\
\end{array}$ & 0.717 & 0.801 & 0.639 & 0.824 & 0.726 & 0.686 & 0.482 \\
\hline $\mathrm{N}$ & 144,247 & 69,467 & 74,780 & 53,010 & 16,457 & 57,731 & 17,049 \\
\hline
\end{tabular}

The dependent variable is a dichotomous indicator that takes the value of one if the person has middle school education as his/her highest level of attained education. Control variables include age, sex, urban residence, year fixed effect (year=2011) and dummies for the 26 provinces of residence. Regressions that included agesquared provided the same results. The sample includes all respondents who were ages 20 to 29 in 2011 and age 20 30 in 2012. Standard errors (in parentheses) are clustered at the province-by-age level (130 clusters) to eliminate correlation between workers of the same age living in the same area $*: p<0.10, * *: p<0.05, * * *: p<0.01$ 


\section{Table 3}

The Effectiveness of the Reform in Increasing the Propensity for Middle School Completion

(People 20 to 30 Years of Age and Highest Attained Education is High School or Lower) Dependent Variable: Middle School Completion

\begin{tabular}{|c|c|c|c|c|c|c|c|}
\hline & $\begin{array}{c}\text { Entire } \\
\text { Sample } \\
(1)\end{array}$ & $\begin{array}{l}\text { Males } \\
\text { (2) }\end{array}$ & $\begin{array}{c}\text { Females } \\
\text { (3) }\end{array}$ & $\begin{array}{c}\text { Urban } \\
\text { Males } \\
\text { (4) }\end{array}$ & $\begin{array}{c}\text { Rural } \\
\text { Males } \\
\text { (5) }\end{array}$ & $\begin{array}{c}\text { Urban } \\
\text { Females } \\
(6)\end{array}$ & $\begin{array}{c}\text { Rural } \\
\text { Females } \\
\text { (7) }\end{array}$ \\
\hline $\begin{array}{c}\text { Coefficient } \\
\text { of } \\
\text { Treatment }\end{array}$ & $\begin{array}{c}0.217 * * * \\
(0.019)\end{array}$ & $\begin{array}{c}0.224 * * * \\
(0.016)\end{array}$ & $\begin{array}{c}0.212 * * * \\
(0.029)\end{array}$ & $\begin{array}{c}0.207 * * * \\
(0.018)\end{array}$ & $\begin{array}{c}0.256^{* * * *} \\
(0.029)\end{array}$ & $\begin{array}{c}0.231 * * * \\
(0.030)\end{array}$ & $\begin{array}{c}0.165^{* *} \\
(0.046)\end{array}$ \\
\hline Age & $\begin{array}{r}-0.034 * * \\
(0.003)\end{array}$ & $\begin{array}{c}-0.029 * * * \\
(0.003)\end{array}$ & $\begin{array}{c}-0.038 * * * \\
(0.005)\end{array}$ & $\begin{array}{c}-0.028 * * * \\
(0.003)\end{array}$ & $\begin{array}{c}-0.034 * * * \\
(0.005)\end{array}$ & $\begin{array}{c}-0.033 * * * \\
(0.005)\end{array}$ & $\begin{array}{c}-0.050 * * * \\
(0.008)\end{array}$ \\
\hline Male & $\begin{array}{c}0.198 * * * \\
(0.009)\end{array}$ & . & . & . & . & & . \\
\hline Urban & $\begin{array}{c}0.111^{* * *} * \\
(0.010)\end{array}$ & $\begin{array}{c}0.090 * * * \\
(0.012)\end{array}$ & $\begin{array}{c}0.130 * * * \\
(0.011)\end{array}$ & & . & & . \\
\hline $\begin{array}{l}\text { Year Fixed } \\
\text { Effect }\end{array}$ & $\begin{array}{c}-0.027 * * * \\
(0.005)\end{array}$ & $\begin{array}{c}-0.023 * * * \\
(0.005)\end{array}$ & $\begin{array}{c}-0.030^{* * * *} \\
(0.008)\end{array}$ & $\begin{array}{c}-0.025^{* * *} \\
(0.006)\end{array}$ & $\begin{array}{c}-0.020 * * * \\
(0.010)\end{array}$ & $\begin{array}{c}-0.022 * * * \\
(0.008)\end{array}$ & $\begin{array}{c}-0.049 * * * \\
(0.011)\end{array}$ \\
\hline $\begin{array}{l}\text { Province } \\
\text { Dummies }\end{array}$ & Y & Y & Y & Y & Y & Y & Y \\
\hline $\begin{array}{c}\text { Mean } \\
\text { Middle } \\
\text { School } \\
\text { Completion } \\
\end{array}$ & 0.591 & 0.697 & 0.502 & 0.721 & 0.630 & 0.542 & 0.393 \\
\hline$N$ & 99,670 & 45,576 & 54,094 & 33,352 & 12,224 & 39,530 & 14,564 \\
\hline
\end{tabular}

The dependent variable is a dichotomous indicator that takes the value of one if the person has middle school education as his/her highest level of attained education. Control variables include age, sex, urban residence, year fixed effect (year=2011) and dummies for the 26 provinces of residence. Regressions that included agesquared provided the same results. The sample includes all respondents who were ages 20 to 29 in 2011 and age 2030 in 2012. Standard errors (in parentheses) are clustered at the province-by-age level (130 clusters) to eliminate correlation between workers of the same age living in the same area $* p<0.10,{ }^{* *}: p<0.05,{ }^{* * *}: p<0.01$ 


\section{Table 4}

Wage Regressions for Workers with Highest Education High School or Lower

\begin{tabular}{|c|c|c|c|c|c|c|}
\hline & \multicolumn{2}{|c|}{ Entire Sample } & \multicolumn{2}{|c|}{ Males } & \multicolumn{2}{|c|}{ Females } \\
\hline & IV & OLS & IV & OLS & IV & OLS \\
\hline Middle School & $0.098^{* *}$ & $0.073^{* * * *}$ & 0.059 & $0.055^{* * *}$ & $0.358^{* *}$ & $0.169 * * *$ \\
\hline Completion & $(0.047)$ & $(0.009)$ & $(0.050)$ & $(0.011)$ & $(0.121)$ & $(0.014)$ \\
\hline & {$[0.039]$} & {$[0.012]$} & {$[0.046]$} & [0.013] & {$[0.120]$} & [0.014] \\
\hline & $\{0.043\}$ & $\{0.005\}$ & $\{0.049\}$ & $\{0.006\}$ & $\{0.096\}$ & $\{0.012\}$ \\
\hline Age & $0.026 * *$ & $0.025 * * *$ & $0.026 * * *$ & $0.026^{* * * *}$ & $\begin{array}{c}0.031 * * * \\
(0006)\end{array}$ & $0.023 * * *$ \\
\hline Male & $0.132 * * *$ & $0.133 * * *$ & & & & \\
\hline Urban Residence & $\begin{array}{c}0.003 \\
(0.011)\end{array}$ & $\begin{array}{c}0.005 \\
(0.011)\end{array}$ & $\begin{array}{c}-0.012 \\
(0.012)\end{array}$ & $\begin{array}{l}-0.012 \\
(0.011)\end{array}$ & $\begin{array}{c}0.068 * * \\
(0.027)\end{array}$ & $\begin{array}{c}0.090^{* * * *} \\
(0.021)\end{array}$ \\
\hline Small Firm & $\begin{array}{c}-0.134 * * * \\
(0.010)\end{array}$ & $\begin{array}{c}-0.135^{* * * *} \\
(0.011)\end{array}$ & $\begin{array}{c}-0.123 * * * * \\
(0.009)\end{array}$ & $\begin{array}{c}-0.123 * * * * \\
(0.010)\end{array}$ & $\begin{array}{c}-0.199 * * * \\
(0.021)\end{array}$ & $\begin{array}{c}-0.193 * * * * \\
(0.020)\end{array}$ \\
\hline $\begin{array}{l}\text { Year Fixed Effect } \\
\text { (2011 dummy) }\end{array}$ & $\begin{array}{c}-0.104^{* * * * *} \\
(0.005) \\
\end{array}$ & $\begin{array}{c}-0.105 * * * * \\
(0.005)\end{array}$ & $\begin{array}{c}-0.104^{* * * *} \\
(0.006)\end{array}$ & $\begin{array}{c}-0.104^{* *} \\
(0.005)\end{array}$ & $\begin{array}{c}-0.107 * * * \\
(0.012) \\
\end{array}$ & $\begin{array}{c}-0.113^{* * * *} \\
(0.012)\end{array}$ \\
\hline Province Dummies & $\mathrm{Y}$ & $\mathrm{Y}$ & $\mathrm{Y}$ & $\mathrm{Y}$ & $\mathrm{Y}$ & $\mathrm{Y}$ \\
\hline Mean Wage & 3.63 & 3.63 & 3.70 & 3.70 & 3.33 & 3.33 \\
\hline $\begin{array}{l}\text { Coefficient of } \\
\text { Treatment in the } 1^{\text {st }} \\
\text { Stage Regression }\end{array}$ & $\begin{array}{c}0.257 * * * \\
(0.021)\end{array}$ & & $\begin{array}{c}0.248 * * * \\
(0.022)\end{array}$ & . & $\begin{array}{c}0.276^{* * * *} \\
(0.047)\end{array}$ & . \\
\hline $\begin{array}{l}\text { F-Statistic of the } \\
\text { Instrument }\end{array}$ & 153.15 & & 123.14 & & 34.31 & \\
\hline $\mathrm{N}$ & 23,854 & 23,854 & 19,352 & 19,352 & 4,520 & 4,520 \\
\hline
\end{tabular}

The dependent variable is the log of nominal wages. The table reports both IV and OLS estimates for the whole sample (everyone who was ages 20-29 in 2011 or 20-30 in 2012 who was working full time) as well as males and females in the sample. The instrument is being born in the cohort exposed to the legislation. All regressions control for age, sex, urban residence, firm size, year fixed effects and province of residence. Standard errors (in parentheses) are clustered at the province-by-age level (130 clusters) to eliminate correlation between workers of the same age living in the same area. Standard errors in straight brackets [] are clustered at the treatment-by-province level (52 clusters) and standard errors in curly brackets \{\} are robust standard errors $* p<0.10, * * p<0.05, * * * p<0.01$ 
Table 5

Instrumental Variables Wage Regressions for Workers with Various Levels of Education Males

\begin{tabular}{|c|c|c|c|c|}
\hline \multicolumn{5}{|c|}{ Highest Level of Education } \\
\hline & $\begin{array}{l}\text { Middle School } \\
\text { or Less } \\
\text { (1) }\end{array}$ & $\begin{array}{l}\text { High School or } \\
\text { Less } \\
(2)\end{array}$ & $\begin{array}{c}\text { High } \\
\text { School/Vocation } \\
\text { al School or less } \\
\text { (3) }\end{array}$ & $\begin{array}{l}\text { All Education } \\
\text { Levels } \\
\text { (4) }\end{array}$ \\
\hline $\begin{array}{l}\text { Middle School } \\
\text { Completion }\end{array}$ & $\begin{array}{c}0.044 \\
(0.041)\end{array}$ & $\begin{array}{c}0.059 \\
(0.050)\end{array}$ & $\begin{array}{c}0.053 \\
(0.060)\end{array}$ & $\begin{array}{l}-0.142 \\
(0.098)\end{array}$ \\
\hline Age & $\begin{array}{c}0.024 * * * \\
(0.004)\end{array}$ & $\begin{array}{c}0.026 * * * \\
(0.004)\end{array}$ & $\begin{array}{l}0.026 * * * \\
(0.003)\end{array}$ & $\begin{array}{l}0.032 * * * \\
(0.004)\end{array}$ \\
\hline $\begin{array}{c}\text { Urban } \\
\text { Residence }\end{array}$ & $\begin{array}{l}-0.005 \\
(0.011)\end{array}$ & $\begin{array}{l}-0.012 \\
(0.012)\end{array}$ & $\begin{array}{l}-0.007 \\
(0.012)\end{array}$ & $\begin{array}{c}0.048 \\
(0.013)\end{array}$ \\
\hline Small Firm & $\begin{array}{c}-0.115^{* * *} \\
(0.010)\end{array}$ & $\begin{array}{c}-0.123 * * * \\
(0.009)\end{array}$ & $\begin{array}{c}-0.142 * * * \\
(0.008)\end{array}$ & $\begin{array}{c}-0.277 * * * \\
(0.014)\end{array}$ \\
\hline $\begin{array}{c}\text { Year Fixed } \\
\text { Effect }(2011)\end{array}$ & $\begin{array}{c}-0.096 * * * \\
(0.007)\end{array}$ & $\begin{array}{c}-0.104 * * * \\
(0.006)\end{array}$ & $\begin{array}{c}-0.101 * * * \\
(0.005)\end{array}$ & $\begin{array}{c}-0.121 * * * \\
(0.009)\end{array}$ \\
\hline $\begin{array}{l}\text { Province } \\
\text { Dummies }\end{array}$ & $\mathrm{Y}$ & Y & Y & $\mathrm{Y}$ \\
\hline Mean Wage & 3.58 & 3.70 & 3.83 & 4.62 \\
\hline $\begin{array}{c}\text { Coefficient of } \\
\text { Treatment in the } \\
1^{\text {st }} \text { Stage } \\
\text { Regression }\end{array}$ & $\begin{array}{c}0.302 * * * \\
(0.028)\end{array}$ & $\begin{array}{c}0.228 * * * \\
(0.022)\end{array}$ & $\begin{array}{c}0.197 * * * \\
(0.017)\end{array}$ & $\begin{array}{c}0.143 * * * \\
(0.013)\end{array}$ \\
\hline $\begin{array}{l}\text { F-Statistic of the } \\
\text { Instrument }\end{array}$ & 125.63 & 123.14 & 129.00 & 113.26 \\
\hline $\mathrm{N}$ & 15,027 & 19,352 & 25,067 & 31,336 \\
\hline
\end{tabular}

The dependent variable is the log wages. The table reports IV estimates for males in the whole sample (everyone who was ages 20-29 in 2011 or 20-30 in 2012 who was working full time) at various levels of education. These cutoffs are middle school or less, high school or less, high school or vocational school or less, and all education levels, respectively. The instrument is being born in the cohort exposed to the legislation. All regressions control for age, urban residence, firm size, year fixed effects and province of residence. Standard errors (in parentheses) are clustered at the province-by-age level (130 clusters) to eliminate correlation between workers of the same age living in the same area. ${ }^{*} p<0.10, * * p<0.05$, *** $p<0.01$ 


\section{Table 6}

Instrumental Variables Wage Regressions for Workers with Various Levels of Education Females

\section{Highest Level of Education}

\begin{tabular}{|c|c|c|c|c|}
\hline & $\begin{array}{l}\text { Middle School } \\
\text { or Less } \\
\text { (1) }\end{array}$ & $\begin{array}{l}\text { High School or } \\
\text { Less } \\
(2)\end{array}$ & $\begin{array}{c}\text { High } \\
\text { School/Vocation } \\
\text { al School or less } \\
\text { (3) }\end{array}$ & $\begin{array}{l}\text { All Education } \\
\text { Levels } \\
\text { (4) }\end{array}$ \\
\hline $\begin{array}{l}\text { Middle School } \\
\text { Completion }\end{array}$ & $\begin{array}{c}0.152 \\
(0.127)\end{array}$ & $\begin{array}{l}0.358^{* * *} \\
(0.121)\end{array}$ & $\begin{array}{l}0.255^{*} \\
(0.138)\end{array}$ & $\begin{array}{c}0.645^{* * *} \\
(0.267)\end{array}$ \\
\hline Age & $\begin{array}{l}0.017 * \\
(0.010)\end{array}$ & $\begin{array}{c}0.031 * * * \\
(0.006)\end{array}$ & $\begin{array}{c}0.028 * * * \\
(0.005)\end{array}$ & $\begin{array}{c}0.064 * * * \\
(0.004)\end{array}$ \\
\hline $\begin{array}{c}\text { Urban } \\
\text { Residence }\end{array}$ & $\begin{array}{c}0.086^{* * *} \\
(0.026)\end{array}$ & $\begin{array}{c}0.068^{* * *} \\
(0.027)\end{array}$ & $\begin{array}{c}0.081 * * \\
(0.028)\end{array}$ & $\begin{array}{c}0.043 \\
(0.038)\end{array}$ \\
\hline Small Firm & $\begin{array}{c}-0.188 * * * \\
(0.015) \\
\end{array}$ & $\begin{array}{c}-0.199 * * * \\
(0.021) \\
\end{array}$ & $\begin{array}{c}-0.195 * * * \\
(0.019) \\
\end{array}$ & $\begin{array}{c}-0.306 * * * \\
(0.017) \\
\end{array}$ \\
\hline $\begin{array}{l}\text { Year Fixed } \\
\text { Effect (2011) }\end{array}$ & $\begin{array}{c}-0.128^{* * * *} \\
(0.015)\end{array}$ & $\begin{array}{c}-0.107 * * * \\
(0.012)\end{array}$ & $\begin{array}{c}-0.109 * * * \\
(0.008)\end{array}$ & $\begin{array}{c}-0.100^{* * * *} \\
(0.008)\end{array}$ \\
\hline $\begin{array}{l}\text { Province } \\
\text { Dummies } \\
\end{array}$ & $\mathrm{Y}$ & $\mathrm{Y}$ & Y & $\mathrm{Y}$ \\
\hline Mean Wage & 3.04 & 3.33 & 3.58 & 5.26 \\
\hline $\begin{array}{c}\text { Coefficient of } \\
\text { Treatment in the } \\
1^{\text {st }} \text { Stage } \\
\text { Regression }\end{array}$ & $\begin{array}{c}0.292 * * * \\
(0.051)\end{array}$ & $\begin{array}{c}0.276 * * * \\
(0.047)\end{array}$ & $\begin{array}{c}0.199 * * * \\
(0.034)\end{array}$ & $\begin{array}{c}0.132 * * * \\
(0.026)\end{array}$ \\
\hline $\begin{array}{c}\text { F-Statistic of the } \\
\text { Instrument }\end{array}$ & 32.20 & 34.31 & 33.85 & 25.25 \\
\hline $\mathrm{N}$ & 2,762 & 4,520 & 6,206 & 11,218 \\
\hline
\end{tabular}

The dependent variable is the log of nominal wages. The table reports IV estimates for females in the whole sample (everyone who was ages 20-29 in 2011 or 20-30 in 2012 who was working full time) at various levels of education. These cutoffs are middle school or less, high school or less, high school or vocational school or less, and all education levels, respectively. The instrument is being born in the cohort exposed to the legislation. All regressions control for age, urban residence, firm size, year fixed effects and province of residence. Standard errors (in parentheses) are clustered at the province-by-age level (130 clusters) to eliminate correlation between workers of the same age living in the same area. $* p<0.10, * * p<0.05, * * * p<0.01$ 


\section{$\underline{\text { Appendix }}$}

\section{Spillover Effects of the Reform}

My findings show that one significant side effect of the reform was to increase people's propensity to complete levels of schooling beyond just middle school. Appendix Table 1 shows that the reform led to a 5.4 percentage point increase in probability of high school or college completion, while it decreased the probability of vocational school completion by 2.0 percentage points. Furthermore, when the propensity to complete college alone is considered, we see that the reform made students 6.0 percentage points more likely to complete that level of higher education.

\section{Potential Selection Problems}

One potential concern in my analysis is the possibility that people are selecting into labor force, full time work or their industry of employment as a result of their level of attained education. In other words, what if more education as a result of the reform causes people to enter the labor force, work fulltime (where they would have worked part time or not at all before) or causes people to work in a high skill industry over a low skill industry? If this is the case, I should see significant coefficients for regression that predict these outcomes as a result of treatment under the reform. If such a selection problem exists, then there would be correlation between the instrument and the controls in the regression, thus confounding what appears to be a significant coefficient in my analysis. To show that this is not the case, I run the aforementioned regressions and show that the impact of education on these outcomes is indeed not significant. These results are displayed in Appendix Tables 2-4. 


\section{Appendix Table 1}

The Effectiveness of the Reform in Increasing the Propensity to Complete High School, Vocational School, or College

\begin{tabular}{|c|c|c|c|}
\hline & $\begin{array}{c}\text { High school or } \\
\text { College (no } \\
\text { vocational school) }\end{array}$ & $\begin{array}{l}\text { Vocational high } \\
\text { school only }\end{array}$ & $\begin{array}{c}\text { College or } \\
\text { higher }\end{array}$ \\
\hline \multicolumn{4}{|c|}{ Entire Sample } \\
\hline Coefficient of & $0.054 * * *$ & $-0.020 * * *$ & $0.060 * * *$ \\
\hline Treatment & $(0.010)$ & $(0.005)$ & $(0.015)$ \\
\hline \multirow{2}{*}{ Age } & $-0.007 * * *$ & $-0.006 * * *$ & $0.017 * * *$ \\
\hline & $(0.002)$ & $(0.001)$ & $(0.003)$ \\
\hline \multirow{2}{*}{ Male } & $0.048 * * *$ & $0.054 * * *$ & $0.011 * *$ \\
\hline & $(0.008)$ & $(0.004)$ & $(0.005)$ \\
\hline \multirow{2}{*}{ Urban Residence } & $0.182 * * *$ & $0.027 * * *$ & $0.098 * * *$ \\
\hline & $(0.008)$ & $(0.004)$ & $(0.006)$ \\
\hline \multirow{2}{*}{ Year fixed effect } & $-0.017 * * *$ & $-0.005 * *$ & $-0.013 * *$ \\
\hline & $(0.004)$ & $(0.002)$ & $(0.004)$ \\
\hline Province Dummies & $Y$ & $Y$ & $Y$ \\
\hline \multirow[t]{2}{*}{$\mathrm{N}$} & 144,247 & 144,247 & 144,247 \\
\hline & & $\underline{\text { Males }}$ & \\
\hline Treatment & $\begin{array}{c}0.019 \\
(0.015)\end{array}$ & $\begin{array}{c}-0.025 * * * \\
(0.007)\end{array}$ & $\begin{array}{l}0.025 * \\
(0.015)\end{array}$ \\
\hline Age & $\begin{array}{c}-0.010 * * * \\
(0.003)\end{array}$ & $\begin{array}{c}-0.008 * * * \\
(0.001)\end{array}$ & $\begin{array}{l}0.015 * * * \\
(0.003)\end{array}$ \\
\hline Urban Residence & $\begin{array}{l}0.179 * * * \\
(0.009)\end{array}$ & $\begin{array}{c}0.006 \\
(0.006)\end{array}$ & $\begin{array}{l}0.095 * * * \\
(0.007)\end{array}$ \\
\hline Year fixed effect & $\begin{array}{c}-0.019 * * \\
(0.005)\end{array}$ & $\begin{array}{l}-0.004 \\
(0.004)\end{array}$ & $\begin{array}{c}-0.018 * * \\
(0.005)\end{array}$ \\
\hline Province Dummies & $Y$ & $\mathrm{Y}$ & $\mathrm{Y}$ \\
\hline \multirow[t]{2}{*}{$\mathrm{N}$} & 69,467 & 69,467 & 69,467 \\
\hline & & Females & \\
\hline Treatment & $\begin{array}{c}0.089 * * * \\
(0.014)\end{array}$ & $\begin{array}{c}-0.014^{*} * \\
(0.006)\end{array}$ & $\begin{array}{c}0.096 * * * \\
(0.019)\end{array}$ \\
\hline Age & $\begin{array}{l}-0.004^{*} \\
(0.003)\end{array}$ & $\begin{array}{c}-0.005 * * * \\
(0.001)\end{array}$ & $\begin{array}{l}0.020 * * * \\
(0.004)\end{array}$ \\
\hline Urban Residence & $\begin{array}{l}0.184 * * \\
(0.008)\end{array}$ & $\begin{array}{l}0.047 * * * \\
(0.004)\end{array}$ & $\begin{array}{c}0.099 * * * \\
(0.006)\end{array}$ \\
\hline Year Fixed effect & $\begin{array}{l}-0.015 * * \\
(0.004)\end{array}$ & $\begin{array}{l}-0.005 * * \\
(0.003)\end{array}$ & $\begin{array}{c}-0.009 * * \\
(0.004)\end{array}$ \\
\hline Province Dummies & $\mathrm{Y}$ & $\mathrm{Y}$ & $\mathrm{Y}$ \\
\hline$N$ & 74,780 & 74,780 & 74,780 \\
\hline
\end{tabular}

Each column has a dependent variable that is a dichotomous indicator that takes the value of one if the person has high school education. Vocational education, or college as his/her highest level of attained education respectively. Control variables include age, sex, urban residence, year fixed effects and dummies for the 26 provinces of residence. Regressions that included agesquared provided the same results. The sample includes all respondents who were ages 20 to 29 in 2011 and 20-30 in 2012. Standard errors (in parentheses) are clustered at the province-by-age level (130 clusters) to eliminate correlation between workers of the same age living in the same area $*: p<0.10, * *: p<0.05, * * *: p<0.01$ 


\section{Appendix Table 2}

The Impact of the Reform on the Probability of working Full time (Respondents with High School or Less), OLS Reduced Form Regressions

\begin{tabular}{|c|c|c|c|c|c|c|}
\hline & \multicolumn{2}{|c|}{ Entire Sample } & \multicolumn{2}{|c|}{ Males } & \multicolumn{2}{|c|}{ Females } \\
\hline Treatment & $\begin{array}{c}-0.016^{* *} \\
(0.007)\end{array}$ & $\begin{array}{l}-0.009 \\
(0.015)\end{array}$ & $\begin{array}{c}0.004 \\
(0.007)\end{array}$ & $\begin{array}{c}0.017 \\
(0.013)\end{array}$ & $\begin{array}{c}-0.025 \\
(0.019)\end{array}$ & $\begin{array}{c}-0.062 \\
(0.045)\end{array}$ \\
\hline Age & $\begin{array}{c}-0.004 * * \\
(0.001)\end{array}$ & - & $\begin{array}{c}0.004 * * \\
(0.001)\end{array}$ & 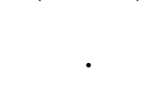 & $\begin{array}{c}-0.013 * * * \\
(0.003)\end{array}$ & \\
\hline Urban & $0.098 * * *$ & $0.098 * * *$ & $0.055 * * *$ & $0.055 * * *$ & $0.174 * * *$ & $0.175 * * *$ \\
\hline Residence & $(0.007)$ & $(0.007)$ & $(0.005)$ & $(0.005)$ & $(0.015)$ & $(0.015)$ \\
\hline Male & $\begin{array}{c}0.191 * * * \\
(0.017)\end{array}$ & $\begin{array}{c}0.191 * * * \\
(0.017)\end{array}$ & & • & & \\
\hline $\begin{array}{l}\text { Year Fixed } \\
\text { Effect }\end{array}$ & $\begin{array}{c}0.001 \\
(0.004) \\
\end{array}$ & $\begin{array}{c}0.002 \\
(0.004)\end{array}$ & $\begin{array}{c}0.003 \\
(0.003) \\
\end{array}$ & $\begin{array}{c}0.005 \\
(0.003) \\
\end{array}$ & $\begin{array}{c}0.003 \\
(0.009) \\
\end{array}$ & $\begin{array}{l}-0.002 \\
(0.010)\end{array}$ \\
\hline $\begin{array}{l}\text { Province } \\
\text { Dummies }\end{array}$ & Y & $\mathrm{Y}$ & $\mathrm{Y}$ & Y & $\mathrm{Y}$ & Y \\
\hline $\begin{array}{l}\text { Age } \\
\text { Dummies }\end{array}$ & $\mathrm{N}$ & $\mathrm{Y}$ & $\mathrm{N}$ & Y & $\mathrm{N}$ & $\mathrm{N}$ \\
\hline$N$ & 45,000 & 45,000 & 32,399 & 32,399 & 12,601 & 12,601 \\
\hline
\end{tabular}

The dependent variable is a dichotomous indicator that takes the value of one if the person was working full time ( 30 hours or more) at the time of the survey. The main independent variable of interest is "Treatment," which is a dichotomous variable that equals one if the respondent was part of the cohort exposed to the reform (age 5-11 in 1997). Control variables include age, sex, urban residence, year fixed effects and dummies for the 26 provinces of residence. Regressions that included age-squared provided the same results. The sample includes all respondents who were ages 20 to 29 in 2011 and 20-30 in 2012. Standard errors (in parentheses) are clustered at the province-byage level (130 clusters) to eliminate correlation between workers of the same age living in the same area $*: p<0.10$, $* *: p<0.05, * * *: p<0.01$

In this regression, the variables are regressed on the treatment dummy, rather than education. This is because the full-time work decision depends on wages and wages depend on education. So, the impact of education cannot be identified independently. As a result, I estimate reduced-form regressions of full-time work and labor force participation. 


\section{Appendix Table 3}

The Impact of the Reform on the Probability of Labor Force Participation, High School or Less Education OLS Reduced Form Regressions

\begin{tabular}{|c|c|c|c|c|c|c|}
\hline \multirow{3}{*}{ Treatment } & \multicolumn{2}{|c|}{ Entire Sample } & \multicolumn{2}{|c|}{ Males } & \multicolumn{2}{|c|}{ Females } \\
\hline & $0.051 * *$ & 0.018 & $0.117 * * *$ & -0.003 & 0.007 & 0.028 \\
\hline & $(0.016)$ & $(0.017)$ & $(0.033)$ & $(0.023)$ & $(0.015)$ & $(0.025)$ \\
\hline$\Delta \mathrm{ar}$ & $0.023 * * *$ & 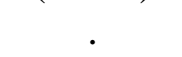 & $0.055^{* * *} *$ & & -0.002 & \\
\hline Age & $(0.003)$ & & $(0.007)$ & - & $(0.003)$ & - \\
\hline Urban & $-0.105 * * *$ & $-0.104 * * *$ & $-0.042 * * *$ & $-0.039 * * *$ & $-0.157 * * *$ & $-0.157 * * *$ \\
\hline Residence & $(0.008)$ & $(0.008)$ & (0.009) & $(0.009)$ & $(0.010)$ & $(0.010)$ \\
\hline Molo & $0.540 * * *$ & $0.538 * * *$ & & & & \\
\hline viale & $(0.019)$ & $(0.019)$ & - & - & • & • \\
\hline Year Fixed & $0.013 * *$ & $0.008^{*}$ & $0.032 * * *$ & $0.017 * *$ & -0.004 & -0.003 \\
\hline Effect & $(0.005)$ & $(0.005)$ & $(0.006)$ & $(0.006)$ & $(0.007)$ & $(0.007)$ \\
\hline $\begin{array}{l}\text { Province } \\
\text { Dummies }\end{array}$ & Y & $\mathrm{Y}$ & Y & Y & Y & Y \\
\hline $\begin{array}{l}\text { Age } \\
\text { Dummies }\end{array}$ & $\mathrm{N}$ & $\mathrm{Y}$ & $\mathrm{N}$ & Y & $\mathrm{N}$ & $\mathrm{N}$ \\
\hline$N$ & 99,670 & 99,670 & 45,576 & 45,576 & 54,094 & 54,094 \\
\hline
\end{tabular}

The dependent variable is a dichotomous indicator that takes the value of one if the respondent is in the labor force. The main independent variable of interest is "Treatment," which is a dichotomous indicator that equals one if the respondent was born in the cohort that was exposed to the reform (age 5-11 in 1997). Control variables include age, sex, urban residence, year fixed effects and dummies for the 26 provinces of residence. Regressions that included age-squared provided the same results. The sample includes all respondents who were ages 20 to 29 in 2011 and 20-30 in 2012. Standard errors (in parentheses) are clustered at the province-by-age level (130 clusters) to eliminate correlation between workers of the same age living in the same area $*: p<0.10, * *: p<$ $0.05, * * *: p<0.01$

In this regression, the variables are regressed on the treatment dummy, rather than education. This is because the labor force participation decision depends on wages and wages depend on education. So, the impact of education cannot be identified independently. As a result, I estimate reduced-form regressions of full-time work and labor force participation. 


\section{Appendix Table 4}

The Impact of Middle School Completion on the Probability of Working in a Small Firm, IV Regressions (Respondents with High School or Less)

\begin{tabular}{lccc}
\hline & Entire Sample & Males & Females \\
\hline Middle School & 0.080 & 0.072 & -0.013 \\
Completion & $(0.065)$ & $(0.062)$ & $(0.107)$ \\
Age & 0.006 & 0.003 & 0.007 \\
& $(0.004)$ & $(0.004)$ & $(0.007)$ \\
Urban & $-0.175^{* * *}$ & $-0.137 * * *$ & $-0.259 * *$ \\
& $(0.014)$ & $(0.014)$ & $(0.031)$ \\
Male & -0.013 & &. \\
\multirow{2}{*}{ Year Fixed Effect } & $(0.018)$ & 0.014 & 0.026 \\
& $0.019 * *$ & $(0.009)$ & $(0.014)$ \\
\hline Province Dummies & $(0.009)$ & $\mathrm{Y}$ & $\mathrm{Y}$ \\
\hline \multirow{2}{*}{ First Stage } & $\mathrm{Y}$ & $0.245 * * * 267 * *$ \\
\multirow{2}{*}{ F Stat } & $0.247^{*} * *$ & $(0.020)$ & $(0.037)$ \\
& $(0.019)$ & 150.18 & 51.61 \\
\hline
\end{tabular}

The dependent variable is a dichotomous indicator that takes the value of one if the respondent works in a small firm, where a small firm is defined as having 10 or fewer employees. The regressions are IV regressions exposure to the reform is instrumented on completing middle school or a higher level of education. Control variables include age, sex, urban residence, year fixed effects and dummies for the 26 provinces of residence. Regressions that included age-squared provided the same results. The sample includes all respondents who were ages 20 to 29 in 2011 and 2030 in 2012 who are working more than 30 hours a week. Standard errors (in parentheses) are clustered at the province-by-age level (130 clusters) to eliminate correlation between workers of the same age living in the same area $*: p<0.10, * *: p<0.05, * * *: p<0.01$ 


\section{References}

Angrist, Joshua D. And Jorn-Steffen Pischke. Mostly Harmless Econometrics. Princeton. Princeton University Press. 2009.

Angrist, Joshua D. and Alan B. Kreuger. „Does Compulsory School Attendance Affect Schooling and Earnings?" The Quarterly Journal of Economics, 106(4) 979-1014, November 1991.

Ashenfelter, Orley and Cecilia Rouse. "Income, Schooling, and Ability: Evidence from a New Sample of Identical Twins." The Quarterly Journal of Economics, 113(1) 253-284, February 1998.

Autor, David H. Frank Levy and Rihcard J. Murnane.” The Skill Content of Recent Technological Change: An Empirical Exploration.” Quarterly Journal of Economics. 2003. 1279-1333.

Brown Charles and James Medoff. "The Employer Size-Wage Effect.” Journal of Political Economy. 1989, 97:5. Pp. 1027-1059.

Cesur, Resul and Naci Mocan. "Does Secular Education Impact Religiosity, Electoral Participation and the Propensity to Vote for Islamic Parties? Evidence from an Education Reform in a Muslim Country.” December 2013. NBER Working Paper No. 19769.

Bonjour, Dorothe, Lynn F. Cherkas, Jonathan E. Haskel, Denise D. Hawkes and Tim D. Spector. "Returns to Education: Evidence from UK Twins." American Economic Review, 93(5): 1799-1812, December 2003.

Brunello, Giorgio, Margherita Fort and Guglielmo Weber. "Changes in Compulsory Schooling, Education and the Distribution of Wages in Europe." The Economic Journal, 119(536):516-539, March 2009.

Card, David. "The Causal Effect of Education on Earnings." in Ashenfelter and Card (eds.) Handbook of Labor Economics. Vol. 34A. Amsterdam. Elsevier Science 1999, pp. 1801-1863.

Chen Paul, and Per-Anders Edin. "Efficiency Wages and Industry Wage Differentials: A Comparison Across Methods of Pay." The Review of Economics and Statistics. 2002, 84(4). Pp. 617-631.

Duflo, Esther. "Schooling and Labor Market Consequences of School Construction in Indonesia: Evidence from an Unusual Policy Experiment." The American Economic Review, 91(4):795-813, September 2001.

Dulger, Ilhan. "Turkey: Rapid Coverage for Compulsory Education - The 1997 Basic 3Education Program. Reducing Poverty, Sustaining Growth - What Works, What Doesn't, and Why A Global Exchange for Scaling Up Success" (World Bank),May 2004. 
Fang, Hai, Karen N. Eggleston, John A. Rizzo, Scott Rozelle and Richard J. Zeckhauser. "The Returns to Education in China: Evidence from the 1986 Compulsory Education Law." NBER Working Paper No: 18189, June 2012.

Finkle, Andrew. What's $4+4+4$ ? Weblog entry. Latitude: The New York Times. March 23, 2012. October 22, 2012 (http://latitude.blogs.nytimes.com/2012/03/23/turkeys-education-reform-bill-isabout-playing-politics-with-pedagogy/)

Gibbons, Robert and Lawrence Katz. 'Does Unmeasured Ability Explain Inter-Industry Wage Differentials?” Review of Economic Studies. 1992, pp. 515-535.

Heckman, James J. and Xuesong Li. "Selection Bias, Comparative Advantage and Heterogeneous Returns to Education: Evidence from China in 2000." Pacific Economic Review, 2004. 9(3), pp. 155-171.

Hoxby, Caroline. "Peer Effects in the Classroom: Learning from Gender and Race Variation.” 2000. National Bureau of Economic Research Working paper No: 7867.

Idson, Todd and Walter Y. Oi, "Workers are More Productive in Large Firms." American Economic Review, May 1999, pp. 104-108.

Juhn, Chinhui, Gergely Ujhelyi and Carolina Villegas-Sanchez. " Men, Women and Machines: How Trade Impacts Gender Inequality.” Journal of Development Economics. 2014. 106; pp. 179193.

Kennedy, Peter E. "Estimation with Correctly Interpreted Dummy Variables in Semilogarithmic Equations," 71(4): 801 American Economic Review 1981

Kreuger, Anne O.. "Rates of Return to Turkish Higher Education.” The Journal of Human Resources, 7 (4):482-499, Fall 1972.

Lavy, Victor and Analia Schlosser. "mechanisms and Impacts of Gender Peer Effects at School." 2011. American Economic Journal: Applied Economics, 392): 1-33

Maurin, Eric and Theodora Xenogiani. "Demand for Education and Labor Market Outcomes: Lessons from the Abolition of Compulsory Conscription Laws." The Journal of Human Resources, 42(4):795-819, 2007.

Oreopoulos, Philip. "Estimating Average and Local Treatment Effects of Education when Compulsory Schooling Laws Really Matter." The American Economic Review. 96(1):152-175, 2006.

Organisation for Economic Co-Operation and Development. Basic Education in Turkey. Reviews of National Policies for Education, 2007. 
Siebert, Thomas. Turkey accused of using school system for 'campaign of Islamisation.' Weblog entry. The National. March 2, 2014. September 25, 2012

(http://www.thenational.ae/news/world/europe/turkey-accused-of-using-school-system-forcampaign-of-islamisation)

Soderbom, Mans, Francis Teal and Anthony Wambugu. "Unobserved Heterogeneity and the Relation between Earnings and Firm Size: Evidence from two Developing Countries." Economics Letters. 2005. pp. 153-159.

Tansel, Aysit, and Yousef Daoud. "Comparative Essay on Returns to Education in Palestine and Turkey.” IZA working paper No: 5907 August 2011.

Tansel, Aysit. "Wage Employment, Earnings and Returns to Schooling for Men and Women in Turkey." Economics of Education Review. 13(4): 305-320, 1994.

Troske Kenneth. "Evidence on the Employer Size-Wage premium from WorkerEstablishment Matched Data." The Review of Economics and Statistics, 1999 81(1). pp. 15-26.

Webbink, Dinand. "Returns to University Education: Evidence from a Dutch Institutional Reform.” Economica, 74 (293 ):113-134, February 2007.

Whitmore, Diane. "Resource and Peer impacts on Girls' Academic Achievement: Evidence from a Randomized Experiment.” American Economic Review, 95(2): 199-203.

The World Bank: Turkey. Washington, DC: The World Bank Group, 2013. www.worldbank.org/en/country/turkey

The World Factbook 2012: Turkey. Washington, DC: Central Intelligence Agency, 2009. https://www.cia.gov/library/publications/the-world-factbook/geos/tu.html

Yuret, Tolga. "Human Capital and Sorting Models Reconsidered.” Istisat Isletme ve Finans May 2010.

Velenchik, Ann D. "Government Intervention, Efficiency Wages and The Employer Size Wage Effect in Zimbabwe.” Journal of Development Economics. 1997, pp. 305-338. 